Article

\title{
Structural Change for a Post-Growth Economy: Investigating the Relationship between Embodied Energy Intensity and Labour Productivity
}

\author{
Lukas Hardt ${ }^{1,2, * \mathbb{C}}$, John Barrett ${ }^{1,3}$, Peter G. Taylor ${ }^{1,2,4,5}$ a and Timothy J. Foxon ${ }^{6}(\mathbb{D}$ \\ 1 Sustainability Research Institute, School of Earth and Environment, University of Leeds, Leeds LS2 9JT, UK; \\ J.R.Barrett@leeds.ac.uk (J.B.); P.G.Taylor@leeds.ac.uk (P.G.T.) \\ 2 UK Energy Research Centre, Central House, 14 Upper Woburn Place, London WC1H 0NN, UK \\ 3 Centre for Research into Energy Demand Solutions, Oxford University Centre for the Environment, \\ University of Oxford, South Parks Road, Oxford OX1 3QY, UK \\ 4 Low Carbon Energy Research Group, School of Chemical and Process Engineering, University of Leeds, \\ Leeds LS2 9JT, UK \\ 5 Centre for Integrated Energy Research, University of Leeds, Leeds LS2 9JT, UK \\ 6 SPRU (Science Policy Research Unit), University of Sussex, Falmer, Brighton BN1 9SL, UK; \\ T.J.Foxon@sussex.ac.uk \\ * Correspondence: ee1412b@leeds.ac.uk
}

Received: 9 December 2019; Accepted: 13 January 2020; Published: 29 January 2020 updates

\begin{abstract}
Post-growth economists propose structural changes towards labour-intensive services, such as care or education, to make our economy more sustainable by providing meaningful work and reducing the environmentally damaging production of material goods. Our study investigates the assumption underlying such proposals. Using a multi-regional input-output model we compare the embodied energy intensity and embodied labour productivity across economic sectors in the UK and Germany between 1995 and 2011. We identify five labour-intensive service sectors, which combine low embodied energy intensity with low growth in embodied labour productivity. However, despite their lower embodied energy intensities, our results indicate that large structural changes towards these sectors would only lead to small reductions in energy footprints. Our results also suggest that labour-intensive service sectors in the UK have been characterised by higher rates of price inflation than other sectors. This supports suggestions from the literature that labour-intensive services face challenges from increasing relative prices and costs. We do not find similar results for Germany, which is the result of low overall growth in embodied labour productivity and prices. This highlights that structural change is closely associated with economic growth, which raises the question of how structural changes can be achieved in a non-growing economy.
\end{abstract}

Keywords: post-growth economics; degrowth; structural change; energy footprint; multiregional input-output databases

\section{Introduction}

Sustainable development requires us to "meet the needs of the present without compromising the ability of future generations to meet their own needs" [1] and this principle has been enshrined in the United Nations Sustainable Development Goals [2]. However, human activities are currently breaching several planetary boundaries, threatening to destroy the ecological life-support systems of our planet for future generations [3,4]. These planetary boundaries represent thresholds in Earth-system processes "which, if crossed, could generate unacceptable environmental change" (p. 472) [3]. Avoiding large-scale environmental crises will require the elimination of greenhouse gas (GHG) emissions, 
significant reductions in energy use and material throughput, as well as the reversal of trends in land-use change and biodiversity loss over the space of mere decades $[5,6]$. The critical challenge of sustainability is therefore how we can provide for human needs while reversing our environmental impacts to stay within the planetary boundaries [7].

One of the key drivers of environmental degradation has been the growth in economic activities, measured by GDP $[8,9]$. Therefore, ecological economists propose that we have to transform the economies of developed countries towards post-growth approaches to address the sustainability challenge [10]. Such post-growth economies are defined as economies that prioritise the reduction of environmental impacts and the enhancements of other measures of prosperity over GDP growth. Similar proposals have been discussed under different names such as degrowth $[11,12]$ or a steady-state economy [13,14]. While these approaches feature some important differences, we focus on their commonalities in this study and will therefore refer to them collectively as post-growth approaches.

One important part of the proposed strategies for achieving the post-growth economy is structural change in economic output and employment away from material production and consumption and towards labour-intensive services such as education, care or repair $[15,16]$. Labour-intensive services are considered to be those services where the value of the service provided is inextricably linked to the labour time invested, so that it is difficult or undesirable to increase labour productivity in these services. We distinguish such labour-intensive services from labour-light services that feature a higher potential for labour productivity growth, such as communication services. The objective for such a structural change towards labour-intensive services in a post-growth economy is three-fold [10]. Firstly, these labour-intensive services are important for human flourishing and can provide meaningful jobs. Secondly, it is considered that such labour-intensive services have lower environmental impact than material goods. Thirdly, as it is undesirable and difficult to improve labour productivity in such service sectors, they can reduce the threat of unemployment in a non-growing economy. However, so far, there has been very little empirical investigation in the post-growth economics literature of which sectors in the economy show the characteristics of labour-intensive services and whether structural changes towards such sectors can contribute to the desired objectives.

In this study, we address this gap in the literature by investigating the relationship between the embodied final energy intensity and embodied labour productivity across economic demand sectors in the UK and Germany. The adoption of a supply-chain perspective, which allows us to examine the embodied energy and labour inputs, is one of the key novelties of our analysis. To our knowledge, we provide the first study that compares embodied energy intensity and embodied labour productivity at a sectoral level, although there are a few examples of similar approaches used to examine the relationship between embodied labour and GHG intensities [17-19]. The supply-chain approach, which is based on input-output analysis, takes into account the labour and energy inputs along the whole global supply chain of sectors. We refer to the calculated measures as 'embodied' energy intensity and 'embodied' labour productivity of different demand sectors, to distinguish them from conventional measures, which we will refer to as 'direct' energy intensity and labour productivity. We consider a supply-chain perspective important for investigating structural change for a post-growth transition, because it allows us to examine whether changes in energy intensity and labour productivity are consistent with the overall goals of the post-growth economy. For example, a conventional perspective cannot show whether changes in direct energy intensity or direct labour productivity in specific sectors have been achieved at the expense of changes in energy or labour inputs in other parts of the supply chain.

Using a supply chain perspective has a long tradition in ecological economics for the calculation of energy, GHG and material footprints associated with the final demand in a particular country [20-23]. Supply chain approaches have also been used in the economics literature on structural change, for example, to investigate the implications of diverging levels of embodied labour-productivity in different sectors for overall economic stability [24,25]. Our study combines these two strands of literature.

Our approach allows us to investigate three important topics regarding the assumptions and feasibility of structural change towards labour-intensive services for a post-growth economy. Firstly, 
it is generally assumed that service sectors, including labour-intensive services, have a lower energy intensity than other sectors. There is evidence that this is the case when measuring the direct energy intensity without taking into account the supply chain [26,27]. However, it is debated how much structural changes towards service sectors in developed countries over the past decades have contributed to reducing the overall energy intensity of economies $[27,28]$. We investigate whether the assumption of lower energy intensity in service sectors holds when a supply-chain perspective is used. In addition, we estimate a second measure of energy use that we consider relevant from a post-growth perspective, namely the embodied energy-labour ratio. We use these measures to answer our first research question:

1. Do service sectors have a lower embodied energy intensity and a lower embodied energy-labour ratio than other sectors?

Secondly, there have been very few systematic assessments of which economic sectors show the characteristics of labour-intensive services desirable for a post-growth economy, although Jackson [10] lists "nutrition, education, care, maintenance and repair, recreation, craft, creativity, culture" (p. 220), as examples. The key characteristics of the labour-intensive services promoted in the post-growth literature are the possibility to provide meaningful jobs, low energy intensity and low rates of labour-productivity growth [10]. For the purpose of our study, we focus on the latter two elements. We therefore identify which sectors show the characteristics of labour-intensive services by answering our second research question:

2. Which sectors feature low embodied energy intensity combined with low rates of growth in embodied labour productivity?

A full discussion on which sectors and activities can be considered as labour-intensive services desirable for a post-growth economy also requires a thorough assessment of the first characteristic, namely whether they can provide meaningful jobs. Such an assessment is beyond the scope of this paper as it requires careful consideration of how to define meaningful work. However, further research conducting such assessments is very important for the development of strategies for a post-growth economy. Mair and Druckman [29] provide a good example of research assessing the potential of the health care sector to provide meaningful jobs.

Thirdly, it has been proposed that labour-intensive services face an economic disadvantage compared to other sectors due to Baumol's cost disease. The theory of Baumol's cost disease, proposed by William Baumol and co-authors [30-33], suggests that sectors with low labour productivity growth rates face relative cost and price increases compared to sectors with high labour productivity growth rates. While Baumol's theory is highly stylised, there is considerable evidence that the processes it describes play a role in shaping the economy in the US [34], the EU [35,36], South Korea [37] and across the OECD $[38,39]$. While there is evidence for the existence of Baumol's theories across these countries and regions, the strength of the effect varies in line with different contexts. Baumol [30] himself suggests that his theory has significant implications for the transition to a sustainable economy, because manufacturing sectors with a high environmental impact are getting continuously cheaper compared to the labour-intensive services with low environmental impacts. We therefore investigate whether we can find evidence for such an effect by answering our third research question:

3. Do sectors with low embodied energy intensity and low rates of growth in embodied labour productivity also have higher rates of price inflation compared to other sectors?

\section{Materials and Methods}

\subsection{Calculating Embodied Energy Intensity and Embodied Labour Productivity}

For our purposes, we define the embodied energy intensity, $t_{E, I}$, in each sector $i$ as the ratio of the supply chain inputs of energy, $g_{E, i}$, and the monetary final demand that is spent in this sector, $y_{i}$ 
(Equation (1)). For embodied labour productivity, $p_{L, i}$, we divide the monetary final demand that is spent in this sector, $y_{i}$, by the supply chain inputs of labour, $g_{L, i}$ (Equation (2)). We define the embodied energy labour ratio in each sector, $r_{i}$, as the ratio of the supply chain inputs of energy, $g_{E, I}$ and the supply chain inputs of labour, $g_{L, i}$ (Equation (3)).

$$
\begin{gathered}
t_{E, i}=\frac{g_{E, i}}{y_{i}} \\
p_{L, i}=\frac{y_{i}}{g_{L, i}} \\
r_{i}=\frac{g_{E, i}}{g_{L, i}}
\end{gathered}
$$

For convenience, we will refer to $g_{E, i}$ and $g_{L, i}$ as energy and labour footprints of the relevant sectors. The footprints measure the energy and labour inputs that are used in all stages along the supply chain of a certain end-product. For example, the energy footprint of the UK demand for goods from the vehicles sector includes any energy that is used around the world in the supply chain, such as any energy used to produce the required steel in China or car parts in Eastern Europe.

We obtain the energy and labour footprints for all sectors of final demand in the UK and Germany using the standard approach based on multi-regional input-output analysis [40,41]. Calculating the energy and labour footprints requires three elements of monetary data that we obtain from the multi-regional input-output (MRIO) database EXIOBASE [42]. Figure 1 shows a graphic representation of an MRIO database and the three elements. The first element is a vector that includes the total economic output for each sector in each country (x). This output represents the sum of all sales, including to intermediate and final demand. The second element is the flow matrix $\mathbf{Z}$ that contains the flow of money from each sector in each country to all other sectors in all countries. These flows represent the intermediate inputs in the production process. In our case, $\mathbf{Z}$ represents a square matrix with $i$ number of rows and $j$ number of columns, where $i$ and $j$ are equal to the number of sectors. The third element is a relevant vector of final demand (y) for which we want to calculate the energy or labour footprint. The vector y gives the sum of global final consumption expenditure by households, non-profit organisations and the government, as well as gross fixed capital formation, changes in inventories and changes in valuables for each sector.

The total output in each sector, $x_{i}$, is equal to the sum of final demand in the sector $y_{i}$ and all the intermediate inputs the sector delivers to other sectors, i.e., the row elements of $\mathbf{Z}$ (Equation (4)).

$$
x_{i}=z_{i, 1}+z_{i, 2}+\ldots z_{i, j}+y_{i}
$$

To obtain the footprints, we firstly need to calculate how much of the economic output from each sector in each country is part of the supply chain for the different demand sectors in each country. This means that we need to express $\mathbf{x}$ as a function of $\mathbf{y}$. To do so we define a matrix $\mathbf{A}$, with the same dimensions as $\mathbf{Z}$, that expresses the total intermediate inputs in each sector, recorded in $\mathbf{Z}$, as a fraction of the total output created in the sector, given in $\mathbf{x}$. The elements of $\mathbf{A}$ are given by Equation (5).

$$
a_{i, j}=\frac{z_{i, j}}{x_{j}}
$$

We can use Equation (5) to substitute the elements of $\mathbf{Z}$ in Equation (4) and obtain in matrix notation:

$$
\mathbf{x}=\mathbf{A x}+\mathbf{y}
$$

Now Equation (6) can be rearranged to express $\mathbf{x}$ as a function of $\mathbf{y}$ :

$$
\mathbf{x}=(\mathbf{I}-\mathbf{A})^{-1} \mathbf{y}=\mathbf{L} \mathbf{y}
$$


where $\mathbf{I}$ is the identity matrix and $\mathbf{L}$ is usually referred to as the Leontief inverse.

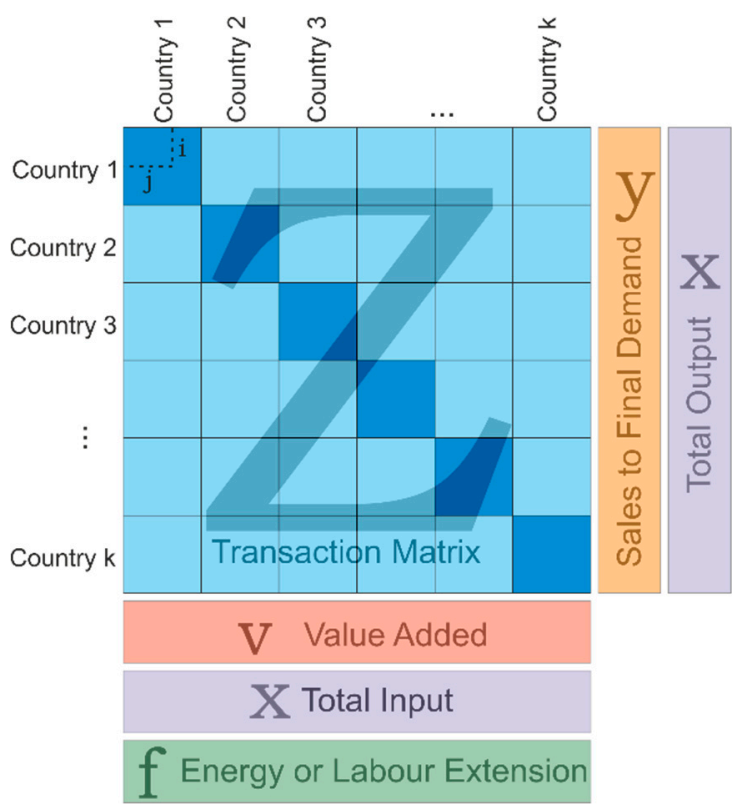

Figure 1. Basic MRIO structure. The $\mathbf{Z}$ matrix contains all inter-sector transactions. Vector $\mathbf{x}$ represents the total economic input or output and vector $\mathbf{y}$ represents sales to final demand. $\mathbf{Z}, \mathbf{x}$ and $\mathbf{y}$ are in financial units. Vector $\mathrm{f}$ is the energy or labour extension, which is in energy or labour units. Adapted from Brockway et al. [43].

Equation (7) can tell us how much economic output from different sectors around the world is embodied in the supply chain of the final demand in different sectors and countries. We can calculate the energy and labour footprints of those final demand sectors by using information on the energy and labour intensity of output in different sectors and different countries that are part of the supply chain. Such extension vectors constitute the fourth element needed for the calculation. The vector $\mathbf{f}_{\mathrm{E}}$ describes the total inputs of energy in each sector in each country. We can divide this by the total output of each sector, $\mathbf{x}$, to obtain the output intensity of energy in each sector (e).

$$
\mathbf{e}=\mathbf{f}_{\mathrm{E}} \hat{\mathbf{x}}^{-1}
$$

A vector with a "hat" () represents a diagonal matrix, whose diagonal elements are the elements of the vector. We can multiply both sides of Equation (7) with e to obtain:

$$
\mathbf{f}_{\mathrm{E}}=\mathbf{e L y}
$$

To calculate the footprints, we can obtain a flow matrix $\mathbf{F}_{\mathrm{E}}$ by diagonalising $\mathbf{e}$ and $\mathbf{y}$ :

$$
F_{E}=\hat{e} L \hat{y}
$$

The flow matrix has the same dimensions as $\mathbf{Z}$. Each column of $\mathbf{F}_{\mathbf{E}}$ shows the supply-chain energy inputs associated with the final demand for the corresponding sector. Summing the columns of $\mathbf{F}_{\mathbf{E}}$ gives the vector that contains the energy footprints associated with each sector of final demand, $g_{E}$. To obtain labour footprints, $\mathbf{g}_{\mathbf{L}}$, the same procedure is employed but using a vector $\mathbf{f}_{\mathbf{L}}$ that describes the total labour inputs and provides a flow matrix $F_{L}$.

To calculate rates, change of over time in prices and intensities we fit a log-linear regression model to the relevant variable over the whole time period to obtain the compound rate of growth in the variable as suggested by Gujarati [44]. 


\subsection{Data Sources}

We use the EXIOBASE V3.4 database [42], to obtain the relevant data of $\mathbf{x}, \mathbf{Z}$, and $\mathbf{y}$ for our analysis. The database covers the period from 1995 to 2011 and represents the global economy using 44 countries and 5 rest-of-the-world regions. EXIOBASE disaggregates the economy into 163 sectors based on the NACE rev. 1.1 classification. However, for our purposes we aggregate all the data to a level of 70 sectors, largely by removing the very detailed sub-classifications in the sectors of agriculture, food production, metal mining and processing and recycling. Labour inputs for each sector and region $\left(\mathbf{f}_{\mathbf{L}}\right)$ were also obtained from EXIOBASE in the form of total hours worked in each year.

Energy inputs for MRIO analysis can be constructed in different ways representing different stages of the energy conversion chain [41]. In this study we are interested in the relationship between energy and labour productivity. Therefore, we focus on inputs at the final energy stage, because we consider those to be closer to the labour inputs than energy inputs at the primary energy stage. At the time of writing, EXIOBASE V3.4 provides a number of energy extension vectors. However, these cover only primary energy inputs (such as primary energy supply) or final energy inputs in the form of gross energy accounts, which cannot be used to calculate energy footprints due to double counting [42]. The final energy extension vector use in the analysis $\left(\mathrm{f}_{\mathrm{E}}\right)$ was therefore prepared by the authors (see Section 2.4).

While EXIOBASE V3.4 covers the whole global economy, we focus on the two countries of Germany and the UK. The reason is that there is very limited information available on final energy consumption in the service sectors in a standardised format covering the global economy over the time period of our analysis (see Section 2.4). As the service sectors are a special focus of our study, we require more detailed information on sectoral final energy consumption in the service sectors than is provided in international energy databases. In the absence of standardised information, such detailed information can only be obtained from national data sources. While such information from national sources is available for many countries, it requires considerable work to obtain and process the relevant data to make it compatible with the input-output database. Obtaining and processing such national data for more than two countries was not possible within the constraints of our study. We chose the UK and Germany as case studies, because they represent two developed nations that have maintained different economic models and industrial structures [45].

\subsection{Preparing the Final Demand Vectors}

The flow matrices $\mathbf{F}_{\mathbf{E}}$ and $\mathbf{F}_{\mathbf{L}}$ can be used to calculate the energy and labour footprints for different subsets of the final demand vector $(\mathbf{y})$. We use two different kinds of such subsets in our analysis.

Firstly, for comparing sector shares in demand and footprints, as well as comparing intensities of sectors in current prices, we try to capture as much as possible of the energy and labour footprints of UK and German final demand. Therefore, we use the final demand from all sources for each economic sector in Germany and the UK respectively. Results of this analysis are presented in Section 3.1.

Secondly, to investigate the rates of change in embodied energy and labour intensities in constant prices we only include the domestic final demand. The reason is that we require sectoral price indices to deflate final demand. These were not available for all countries from which parts of final demand are imported. Therefore, we only investigate the embodied intensities of the domestic components of final demand. This includes all final demand for products in the UK and Germany where the end product is produced domestically. It excludes final demand for imported finished products. However, footprints of this domestic demand still include global inputs of intermediate products along the supply chain. The results of this analysis are presented in Sections 3.2 and 3.3.

To obtain time series of embodied energy and embodied labour productivity for domestic demand in constant prices we first obtain the relevant intensities for each sector in current prices and then deflate the final demand (the denominator) using a price index. For price indices we use the sectoral implied GVA deflators for the UK and Germany provided by the Eurostat database [46]. These were the only price indices that we could obtain in a consistent format covering all sectors in both countries 
and the whole time period. Using the price indices, we produce time series of final demand in constant 2010 prices using chained volume indices [47]. We do not convert the input-tables into constant prices, as for example done by Lan et al. [23], because our analysis is focused on the total energy and labour footprints in each sector and does not analyse how structural changes in the global economy change these values over time. We therefore consider that a deflation of the input-output tables would only add unnecessary uncertainty to our results.

All analysis was conducted at the level of the 70 sectors; we aggregate the results to 25 sectors to reduce the uncertainty related to the footprints and for increased clarity of presentation (Table 1). After the calculation of footprints and intensities some sectors were excluded from the presentation because they do not feature any final energy consumption themselves. These include the energy-producing sectors and the sector of "Private Households with Employed Persons" (see Section 2.4).

Table 1. Sector classification used for presenting results.

\begin{tabular}{ll}
\hline \multicolumn{1}{c}{ Sector } & NACE Codes (Rev. 1.1) \\
\hline Agriculture, Forestry, Fishing & $01,02,05$ \\
Mineral Products & $13,14,26$ \\
Food, Beverages and Tobacco & 15,16 \\
Textiles, Clothes, Leather & $17,18,19$ \\
Paper, Printing, Publishing & 21,22 \\
Chemicals & 24 \\
Metals and Fabricated Metal Products & 27,28 \\
Machinery, Electrical Equipment, Computers & $29,30,31,32,33$ \\
Transport Equipment & 34,35 \\
Other Manufacturing & $20,25,36,37$ \\
Construction & 45 \\
Wholesale and Retail Trade & $50,51,52$ \\
Hotels and Restaurants & 55 \\
Transport & $60,61,62,63$ \\
Finance and Insurance & $65,66,67$ \\
Real Estate Activities & 70 \\
IT and Communication & 64,72 \\
Business Services & $71,73,74$ \\
Public Administration & 75 \\
Health & 85 \\
Education & 80 \\
Other Services & $41,90,91,92,93$ \\
\hline Sectors not Presented in Results & \\
Fuel Producers & $10,11,23$ \\
Production and Distribution of Electricity, Gas, Steam, & 40 \\
Hot Water & 95 \\
Private Households with Employed Persons & \\
\hline
\end{tabular}

A large part of the output and final demand in the Real Estate sector consists of imputed rents for owner-occupied housing. We remove these from the figures for output and demand in the sector to obtain a more realistic value of the embodied labour productivity in the sector. For Germany, no information of the share of imputed rents in the Real Estate sector was available before 2011. Therefore, we only include the sector in the first part of the analysis, which estimates embodied energy intensities and embodied labour productivities in 2011. We exclude the Real Estate sector from the second part of the analysis covering the rates of change in embodied labour productivity. Any aggregate totals of demand, energy footprints and labour footprints that are presented in the following analysis exclude the demand for the energy-producing sectors, private households and imputed rents. 


\subsection{Preparing the Energy Extension Vector}

This section provides a summary of the methods and data sources used to construct the energy extension vector. A more detailed description can be found in the supplementary information.

As outlined above, we focus on the embodied final energy in this study. Final energy use represents any final energy carriers (e.g., petrol, natural gas, electricity) that are consumed by end users, such as firms, households or the government. It excludes any energy that is used in the extraction of primary energy carriers (e.g., oil and gas extraction) or in the transformation of such primary energy into final energy (e.g., oil refineries). Final energy consumption also excludes any losses that occur in the transformation and distribution of energy (e.g., losses in thermal power stations). For brevity we will use the term 'energy' to describe final energy inputs in the reminder of this article.

As outlined above, calculating the footprints of final energy consumption requires information on the final energy inputs into each of the EXIOBASE sectors in each region, captured in the vector $\mathbf{f}_{\mathrm{E}}$. We use a two-stage process to prepare the vector of energy inputs. In the first step we use data on final energy consumption provided by the International Energy Agency (IEA, Paris, France) to construct a complete vector $f_{\mathrm{E}}$ for all countries and regions. In a second step we use national data sources to construct more detailed vectors of energy inputs for Germany and the UK which then replace the relevant entries for the UK and Germany in the vector produced in the first step.

For the first step, we draw on data from the IEA World Energy Balances [48], which provide details on the total final consumption (TFC) of energy in more than 140 countries. The IEA World Energy Statistics and Balances can be downloaded with institutional or other user licence. From TFC, we exclude non-energy use and the energy consumption by private households for residential and transport purposes, because our study focuses on energy inputs into economic production. This leaves us with the relevant final energy consumption in each country disaggregated into 23 IEA flows.

To produce $\mathrm{f}_{\mathrm{E}}$ the IEA countries are firstly aggregated into the 49 EXIOBASE countries and regions. Secondly, the 23 flows of final energy consumption in the IEA data are split and allocated to the 70 EXIOBASE sectors in our analysis. This allocation process requires additional information and assumptions. For most sectors, we split the relevant IEA flows proportionate to monetary output or energy expenditure obtained from EXIOBASE. This approach has the advantage that it can implemented easily and consistently across all countries. However, the assumption of proportionate energy and monetary flows also introduces an amount of uncertainty into the analysis. This is especially the case for the service sectors, as the energy consumption in all service sectors (excluding transport) is represented in a single flow in the IEA energy balances. To address this limitation, we focus our analysis on the UK and Germany and construct more detailed energy inputs for these countries in the second step, paying particular attention to the service sectors. This limits the uncertainty because service sector outputs are traded less than manufactured goods.

A second limitation of the IEA energy balances for our purposes is presented by the fact that they are assembled based on a territorial principle, while national economic accounts and EXIOBASE follow a residency principle [42]. This is particularly problematic for the transport sector. As a detailed modelling of the different transport flows is beyond the resources and time available for this study, we resolve these issues using a number of simplifying assumptions (see Supplementary Information).

In the second step we construct energy input vectors for the UK and Germany using national data sources that offer more detail than the IEA data. For the UK these data sources include the "Energy consumption in the UK" dataset [49] and for Germany the sources include the German energy balances [50] as well as reports on energy use in the service [51-54] and transport sectors [55,56].

\subsection{Limitations}

Constructing the input-output tables, as well as the labour and energy extension vectors covering the global economy presents a challenging task that relies on many assumptions and interpolations to correct for gaps and inconsistencies in the data. Uncertainties in input-output results are difficult to quantify and are not commonly reported [57]. Uncertainties arise from the methods used in constructing 
the input-output tables as well as from the construction and use of extension vectors. Peters, Davis and Andrew [58] compare the aggregate carbon footprints for different countries calculated by different studies. They conclude that the results are broadly consistent and that differences in the footprint results are largely due to differences in extension vectors and differences in definitions for allocating emissions to international trade, rather than differences in the footprinting methods and MRIO databases. Lenzen, Wood and Wiedmann [59] conduct a Monte Carlo analyses to estimate the uncertainty associated with carbon emissions embodied in imports and exports from the UK. They report standard deviations for total embodied emissions in the range of 3-8\%. However, they also highlight that, firstly, uncertainty at the sectoral level can be considerably higher and secondly, that their method cannot capture systematic errors associated with footprint production.

While our results therefore need to be considered with caution, we utilise the best data and methods available and consider the results a useful addition to the post-growth economics literature. More detailed information on underlying assumptions and uncertainties associated with the construction of the EXIOBASE 3 database and the labour extension vector is provided in Stadler et al. [42], while more information on the construction of the energy extension is available in the supplementary information to this article.

\section{Results}

\subsection{Comparing Embodied Energy Intensities across Sectors}

Even though we are using embodied energy intensity measures, our results show that service sectors, with the exception of the transport sector, have a lower embodied energy intensity than other sectors (Figure 2, Table 2). In both countries, the embodied energy intensity of the service sectors is in the range of 0.9-1.9 MJ/EUR, while the production sectors, which include the manufacturing and mining sectors, show values between 3.5 to 7.6 MJ/EUR. An outlier is the Other Manufacturing sector in the UK with 11.0 MJ/EUR. However, this is likely to be an overestimate as it includes all the unclassified industrial energy use in the UK (see Supplementary Information). The Agriculture, Forestry, Fishing sector shows values in the same range as the production sectors (4.3 MJ/EUR and 5.6 MJ/EUR). In both countries the Transport sector has the highest embodied energy intensity with values of 13.2 and 11.0 MJ/EUR. The position of the Construction sector is somewhat different in the two countries. While embodied energy intensity in the Construction sector is in the range of the service sectors in the UK, it sits between the service and manufacturing sectors in Germany (Table 2).

When considering the embodied energy-labour ratios the results are somewhat different from the results for embodied energy intensities. Firstly, the clear distinction between the service sectors and other sectors becomes more blurred. The Textiles, Clothes and Leather sector, the Food, Beverages and Tobacco sector and the Agriculture, Forestry, Fishing sector all have values of the energy-labour ratio that are similar or lower than many service sectors (Table 2). In all of these three sectors, a large proportion of the supply-chain labour inputs are performed abroad in low-wage countries (Tables A1 and A2 in Appendix A). The common perception that the production and agriculture sectors are 'high-energy' is therefore partially the result of ignoring the dependence of some of these sectors on low-wage labour in other parts of the world.

\subsection{Identifying Labour-Intensive Service Sectors}

To investigate the rates of change in embodied labour productivities, we only consider the final demand from domestic sectors in the UK and Germany (see Section 2.3).

Based on our results, we identify five sectors as labour-intensive services. These include the sectors Hotels and Restaurants, Public Administration, Health, Education and Other Services. These five sectors show embodied energy intensities smaller than $2 \mathrm{MJ} / \mathrm{EUR}$ and rates of change in embodied labour productivity smaller than 1\% per year in both countries (Tables 2 and 3, Figure 3). 

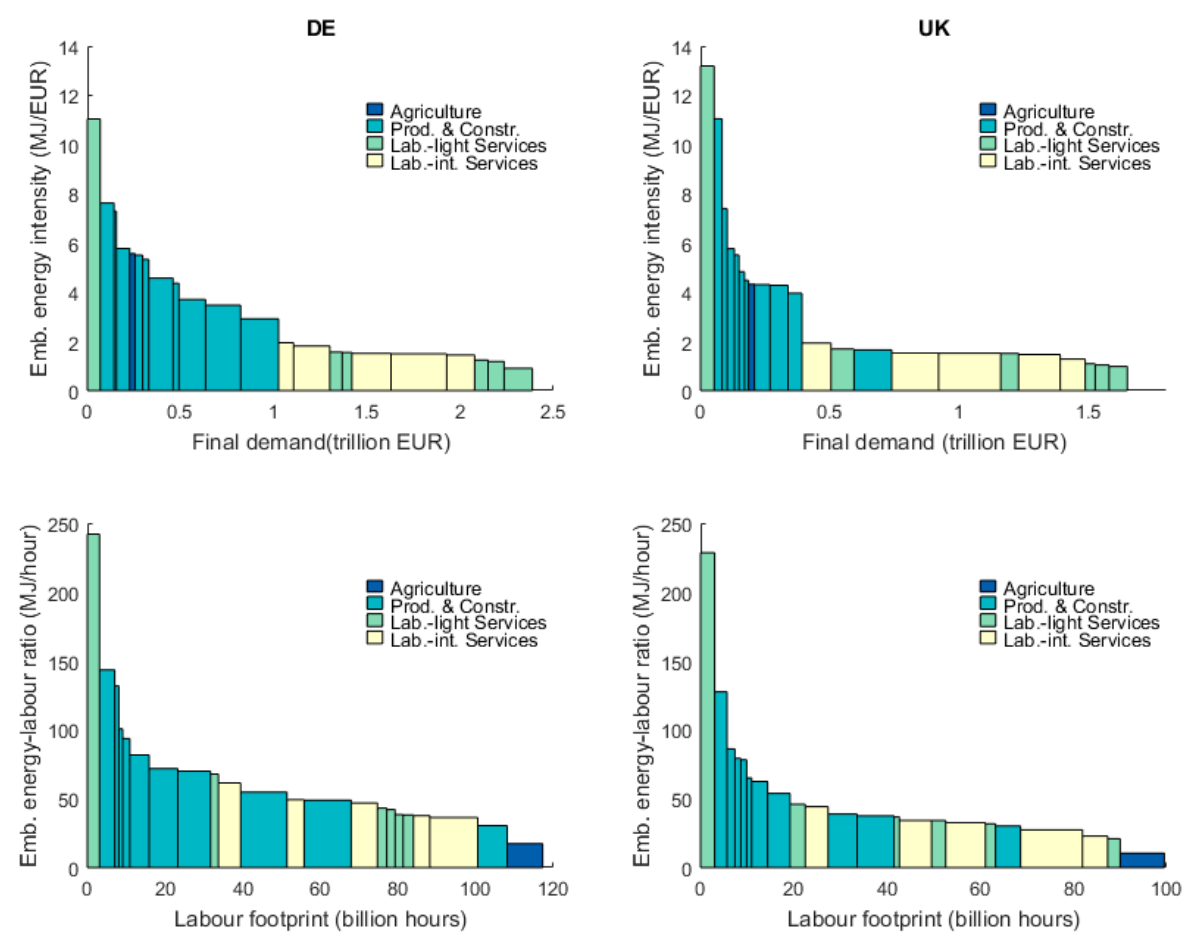

Figure 2. Sectoral embodied energy intensity plotted against sectoral final demand (top row) and sectoral embodied energy-labour ratio plotted against sectoral labour footprint (bottom row). The areas covered by the rectangles represent the total energy footprint in the respective countries (excluding final energy footprints associated with demand for energy-producing sectors).

Table 2. Embodied energy intensities, embodied energy-labour ratios and final demand share in 2011 for the 22 energy-using demand-sectors in the UK and Germany.

\begin{tabular}{|c|c|c|c|c|c|c|}
\hline \multirow[b]{3}{*}{ Demand Sector } & \multicolumn{6}{|c|}{2011} \\
\hline & \multicolumn{3}{|c|}{ UK } & \multicolumn{3}{|c|}{ DE } \\
\hline & $\begin{array}{c}\text { Energy } \\
\text { Intensity } \\
\text { (MJ/EUR) }\end{array}$ & $\begin{array}{l}\text { Energy/Labour } \\
(\mathrm{MJ} / \mathrm{h})\end{array}$ & $\begin{array}{l}\text { Demand } \\
\text { Share }(\%)\end{array}$ & $\begin{array}{c}\text { Energy } \\
\text { Intensity } \\
\text { (MJ/EUR) }\end{array}$ & $\begin{array}{l}\text { Energy/Labour } \\
(\mathrm{MJ} / \mathrm{h})\end{array}$ & $\begin{array}{c}\text { Demand } \\
\text { Share (\%) }\end{array}$ \\
\hline \multicolumn{7}{|l|}{ Agriculture } \\
\hline Agriculture, Forestry, Fishing & 4.3 & 10 & 1.4 & 5.6 & 17 & 1.2 \\
\hline \multicolumn{7}{|l|}{ Production \& Construction } \\
\hline Mineral Products & 4.5 & 65 & 0.9 & 7.3 & 101 & 0.6 \\
\hline Food, Beverages and Tobacco & 4.3 & 38 & 4.2 & 4.6 & 49 & 5.4 \\
\hline Textiles, Clothes, Leather & 5.8 & 30 & 1.7 & 5.5 & 31 & 1.8 \\
\hline Paper, printing, Publishing & 4.8 & 79 & 1.3 & 4.4 & 132 & 1.3 \\
\hline Chemicals & 7.4 & 86 & 1.2 & 7.6 & 143 & 3.1 \\
\hline Metals and Fabricated Metal Products & 5.5 & 78 & 1.1 & 5.3 & 94 & 1.4 \\
\hline Machinery, Electrical, Equipment, Computers & 4.3 & 54 & 3.7 & 3.5 & 55 & 7.9 \\
\hline Transport Equipment & 4.0 & 62 & 3.3 & 3.7 & 72 & 6.0 \\
\hline Other Manufacturing & 11.0 & 128 & 1.8 & 5.8 & 82 & 2.9 \\
\hline Construction & 1.7 & 39 & 8.8 & 2.9 & 70 & 8.5 \\
\hline \multicolumn{7}{|l|}{ Labour-light Services } \\
\hline Wholesale and Retail Trade & 1.7 & 46 & 5.4 & 1.5 & 38 & 2.2 \\
\hline Transport & 13.2 & 229 & 3.2 & 11.0 & 242 & 2.9 \\
\hline Finance and Insurance & 1.0 & 32 & 4.2 & 1.2 & 38 & 3.6 \\
\hline Real Estate Activities & 1.5 & 34 & 4.2 & 0.9 & 68 & 6.4 \\
\hline IT and Communication & 1.0 & 21 & 3.3 & 1.2 & 42 & 3.0 \\
\hline Business Services & 1.1 & 36 & 2.3 & 1.6 & 43 & 2.8 \\
\hline \multicolumn{7}{|l|}{ Labour-intensive Services } \\
\hline Hotels and Restaurants & 1.3 & 23 & 5.9 & 1.9 & 38 & 3.4 \\
\hline Public Administration & 1.5 & 34 & 9.8 & 1.5 & 47 & 8.8 \\
\hline Health & 1.5 & 33 & 11.0 & 1.4 & 49 & 6.3 \\
\hline Education & 1.5 & 27 & 14.6 & 1.5 & 36 & 12.5 \\
\hline Other Services & 1.9 & 44 & 6.8 & 1.8 & 61 & 8.1 \\
\hline Total * & 2.6 & 44 & 100 & 2.9 & 59 & 100 \\
\hline
\end{tabular}

*: Totals exclude demand and energy and labour inputs for the energy-producing sectors, private households and imputed rents. 
Table 3. Rates of change in embodied energy intensity and embodied labour productivity as well as in the embodied energy-labour ratio for domestic demand sectors. Intensities represent embodied energy and labour inputs per unit real demand (const. 2010 EUR).

\begin{tabular}{|c|c|c|c|c|c|c|}
\hline \multirow[b]{3}{*}{ Sector } & \multicolumn{6}{|c|}{ Cumulative Annual Growth Rate between 1995 and 2011 (\%) } \\
\hline & \multicolumn{3}{|c|}{ UK } & \multicolumn{3}{|c|}{ DE } \\
\hline & Energy Intensity & Labour Prod. & Price Index & Energy Intensity & Labour Prod. & Price Index \\
\hline Agriculture, Forestry, Fishing & -4.7 & 3.3 & -2.2 & -3.3 & 2.4 & -1.4 \\
\hline \multicolumn{7}{|l|}{ Production \& Construction } \\
\hline Mineral Products & 1.6 & -2.7 & 2.2 & -0.7 & 0.3 & 0.6 \\
\hline Paper, printing, Publishing & -1.8 & 2.3 & -0.3 & -1.9 & 3.0 & -1.6 \\
\hline Chemicals & -4.8 & 3.3 & -0.9 & -0.4 & 0.1 & -0.1 \\
\hline Metals and Fabricated Metal Products & -3.6 & 1.9 & -0.6 & -2.4 & 0.5 & 1.0 \\
\hline $\begin{array}{l}\text { Machinery, Electrical, Equipment, } \\
\text { Computers }\end{array}$ & -4.3 & 3.3 & -1.8 & -2.5 & 0.6 & -1.2 \\
\hline Transport Equipment & -4.6 & 3.4 & -1.0 & -1.5 & -0.6 & 0.9 \\
\hline Transport & -2.4 & 1.6 & 0.3 & 0.1 & 0.4 & 0.9 \\
\hline Finance and Insurance & -4.5 & 3.5 & 2.0 & 6.0 & -5.2 & 9.1 \\
\hline Real Estate Activities & - & - & - & - & - & - \\
\hline IT and Communication & -6.5 & 6.9 & -3.8 & -2.6 & 3.8 & -3.8 \\
\hline Business Services & -3.8 & 2.6 & 0.5 & -0.2 & -1.3 & 0.8 \\
\hline \multicolumn{7}{|l|}{ Labour-intensive Services } \\
\hline Hotels and Restaurants & -1.4 & 0.0 & 1.6 & -0.9 & 0.9 & 2.2 \\
\hline Public Administration & -1.6 & -0.5 & 2.6 & -2.1 & 0.8 & 0.9 \\
\hline Health & -0.8 & -2.5 & 4.9 & -0.9 & -1.3 & 2.2 \\
\hline Education & -0.7 & 0.6 & 1.8 & -1.0 & 0.1 & 0.3 \\
\hline Other Services & -0.7 & 0.0 & 3.6 & -1.0 & -0.3 & 1.6 \\
\hline Total domestic demand & -2.3 & 0.8 & 1.5 & -1.1 & -0.1 & 0.7 \\
\hline
\end{tabular}
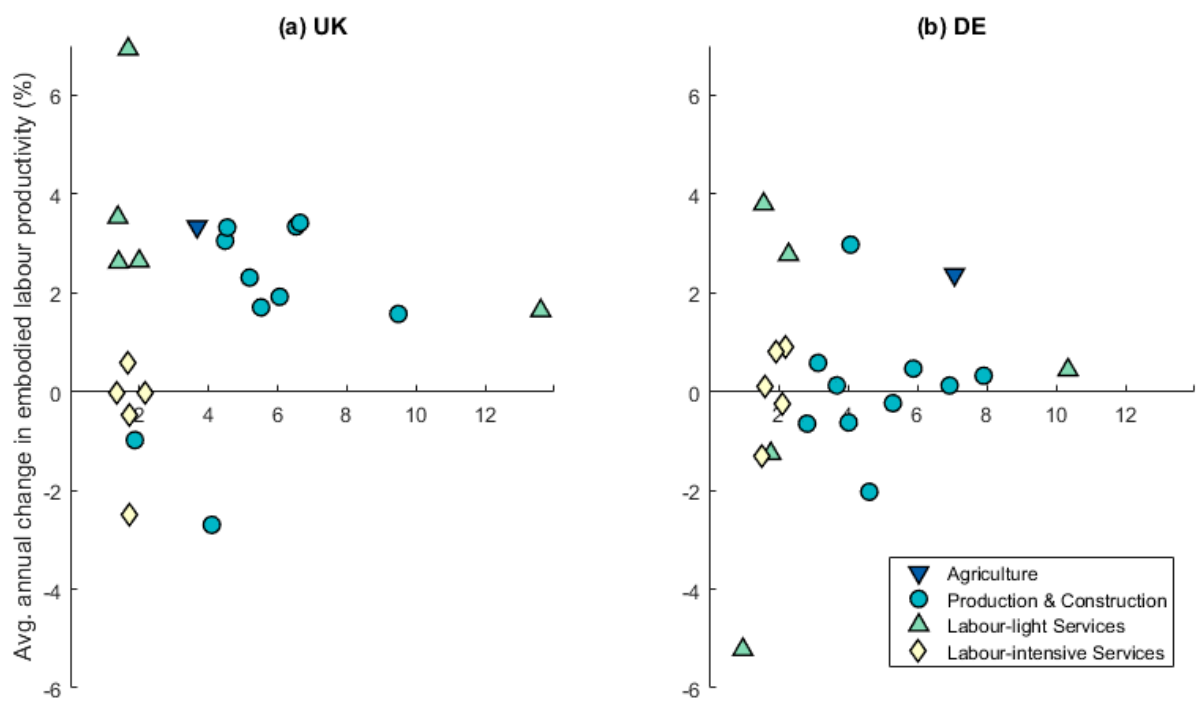

Avg. embodied energy intensity (MJ/const. 2010 EUR)

Figure 3. Relationship between change in embodied labour productivity and the average embodied energy intensity for domestic demand sectors between 1995 and 2011 in (a) the UK and (b) Germany.

The remaining service sectors with low embodied energy intensity show either higher rates of growth in embodied labour productivity in at least one of the two countries. We will be referring to this group of sectors as labour-light services. The Wholesale and Retail Trade sector and the IT and Communications sector show consistently higher rates of growth in embodied labour productivity in both countries, well exceeding $2 \%$ and $3 \%$ per year respectively (Table 3, Figure 3 ). In contrast the results for the Finance and Insurance sector and the Business Services sector diverge between the two 
countries. Both these sectors show relatively high rates of growth in embodied labour productivity in the UK but negative rates of change Germany.

The Finance and Insurance sector in Germany presents a strong outlier with rates of change in embodied labour productivity of $-5.2 \%$ driven by an increase in the price index by $9.1 \%$. This is not a result of the financial crisis as the rates of change in embodied labour productivity and prices between 1995 and 2006 are similar (Table A3, Appendix B). However, the rate of change in direct labour productivity of GVA is much less extreme showing $-0.6 \%$ per year (Table A4, Appendix C). This could indicate that, for this sector, the use of the implied GVA deflator is not well suited to deflate final demand. This is likely to be related to the challenges associated with measuring real output in the sector in general $[60,61]$.

The low rates of direct labour productivity growth in the labour-intensive service sectors is often contrasted with high rates of direct labour productivity growth in the manufacturing, transport and agriculture sectors $[26,62]$. However, our results using supply-chain perspective only fit this pattern in the UK but not in Germany.

In the UK, the production sectors, the Transport sector, as well as the Agriculture, Forestry, Fishing sector show rates of growth in embodied labour productivity that are considerably higher than in the labour-intensive services, ranging from $1.6 \%$ to $3.4 \%$ per year (Table 3, Figure 3a). The only exception is the Mineral Products sector, which records a considerable reduction in embodied labour productivity over the time period studied.

The results for Germany differ considerably from the UK. Most strikingly the production sectors as well as the Transport sector show only very low growth rates or even reductions in embodied labour productivity over the time period studied (Table 3). The only exception is the sector Paper, Printing and Publishing which shows a rate of change in the embodied labour productivity of $3 \%$ per year. Similar to the UK, the Agriculture, Forestry, Fishing sector also shows relatively high rates of growth in embodied labour productivity of $2.4 \%$ per year.

The low rates of growth in embodied labour productivity in the German production sectors are not a result of low growth in the direct labour productivity of the German production sectors themselves. Calculating the growth of direct labour productivity, in the form of GVA in constant 2010 prices per hour of work, shows relatively high and positive rates of growth in the German manufacturing sectors over the same time period (Table A4, Appendix C). The low rates of embodied labour productivity growth are therefore the result of low direct labour productivity growth in other parts of the supply chain offsetting the direct labour productivity growth in German production sectors. A similar effect can also be observed for the UK, with direct labour productivity growth rates in the production sectors being higher than the growth in embodied labour productivity (Table A4, Appendix C). However, the effect is weaker so that the embodied rates of growth are still relatively large and positive for the UK.

The time period covered by our results includes the financial crisis starting in 2008, which could have a distorting impact on our results. We therefore conducted the same analysis covering only the time period from 1995 to 2006 . While restricting the time period changes the results for some sectors, especially some UK manufacturing sectors, the overall patterns are very similar to the ones described for the full time period (Figures A1 and A2 and Table A3, Appendix B).

We can now compare the importance of the different sector groups in the energy footprint, labour footprint and final demand of the two countries. Such a comparison reveals some common features across both countries (Figure 4). The share of the two service sector groups makes up the majority of final demand, but their combined share in the energy and labour footprints is much smaller. Of the two service sector groups, the labour-intensive services take up a considerably bigger share than the labour-light services in final demand and the labour footprint. The difference between the energy footprint shares of the labour-intensive services and the labour-light services is much smaller, because the labour-light service sectors include the large energy footprint of the transport sector. The main 
difference between the two countries is the related to the sector group Production \& Construction, which has considerably bigger share in Germany across all three categories.

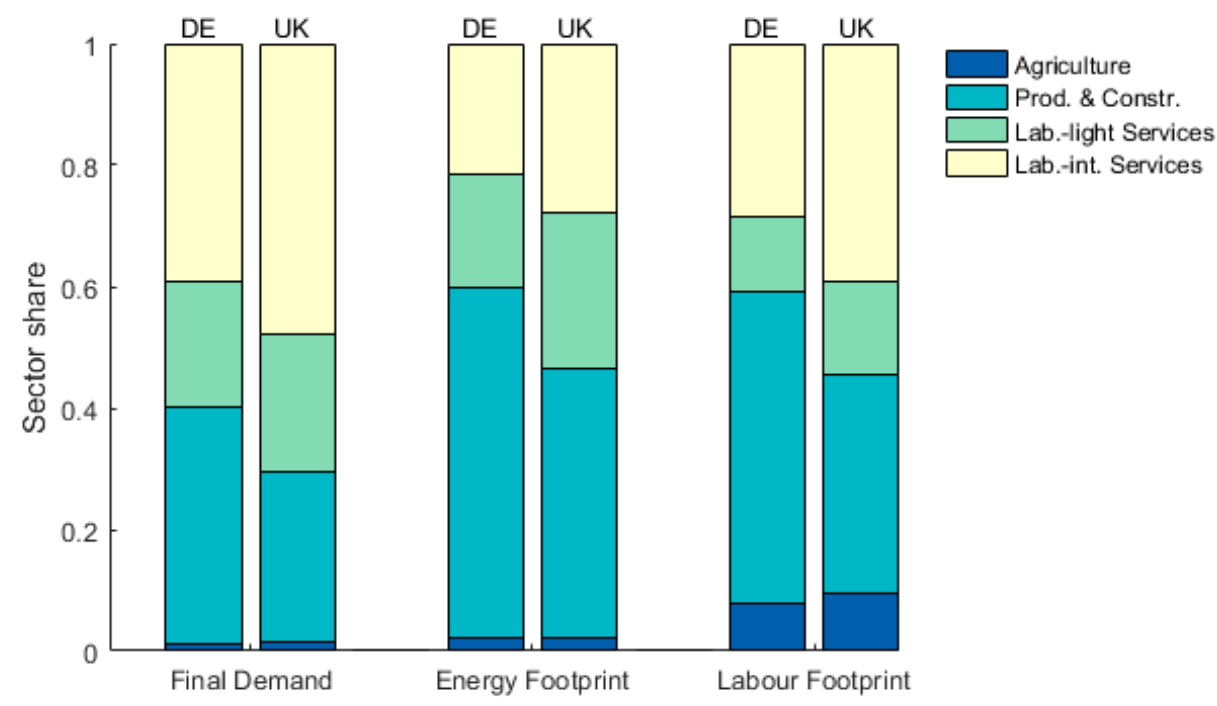

Figure 4. The shares in total final demand, energy footprint and labour footprint in the UK and Germany associated with different demand sectors for the year 2011. Totals exclude demand and energy/labour inputs for the energy-producing sectors, private households and imputed rents.

\subsection{Evidence of Baumol's Cost Disease in Low-Energy Sectors}

Baumol [30] highlights that the cost disease might have negative environmental consequences if the environmentally damaging products from sectors of high environmental impact and high labour productivity growth get continuously cheaper compared to the services provided by low-energy services with low labour productivity growth. This has important implications for the labour-intensive services proposed for a post-growth economy, as these would fall into the latter category.

To test Baumol's suggestion, we investigate the relationship between the embodied energy-labour ratio and the rate of change in the price index. We use the embodied energy-labour ratio instead of the embodied energy intensity because the former can be calculated independent of the price index.

We find that the results for the UK largely support Baumol's suggestion. The labour-intensive service sectors, as well as the Construction sector, show low embodied energy-labour ratios combined with relatively high rates of price inflation, ranging from $1.6 \%$ to $4.9 \%$ per year. In contrast, the production sectors as well as the Transport sector and the Agriculture, Forestry, Fishing sector show higher energy-labour ratios combined with falling prices (Figure 5a, Table 3). Exceptions to this pattern are the sectors Mineral Products and Other Manufacturing, which show increases in prices despite high embodied energy-labour ratios. For the labour-light service sectors the results are mixed. They show a wide range of price inflation rates ranging from $-3.8 \%$ per year in IT and Communications to low rates of increase in Business Services (0.5\%) and higher rates in Wholesale and Retail Trade $(1.4 \%)$ and Finance and Insurance (2.0\%).

For Germany, the results are less clear cut. Overall the rates of price inflation in the labour-intensive services are much lower than in the UK, ranging from $0.3 \%$ to $2.2 \%$ per year. The rates of price inflation in the labour-intensive service sectors are also not distinctly higher than the rates in many of the production sectors, with the latter exhibiting a wide range of values from $-1.6 \%$ to $1.3 \%$ (Figure $5 b$ ). The lack of a clear distinction in price inflation rates between labour-intensive services and production sectors is not surprising given that there is also less of a distinction in the rates of change in embodied labour productivity, discussed in Section 3.2. Similar to the UK the labour-light services show a wide range of price inflation rates ranging from falling prices in IT and Communications $(-3.8 \%)$ and 
Wholesale and Retail Trade $(-0.4 \%)$, over low rates of increase in Business Services $(0.8 \%)$ to extremely high rates in Finance and Insurance (9.1\%).

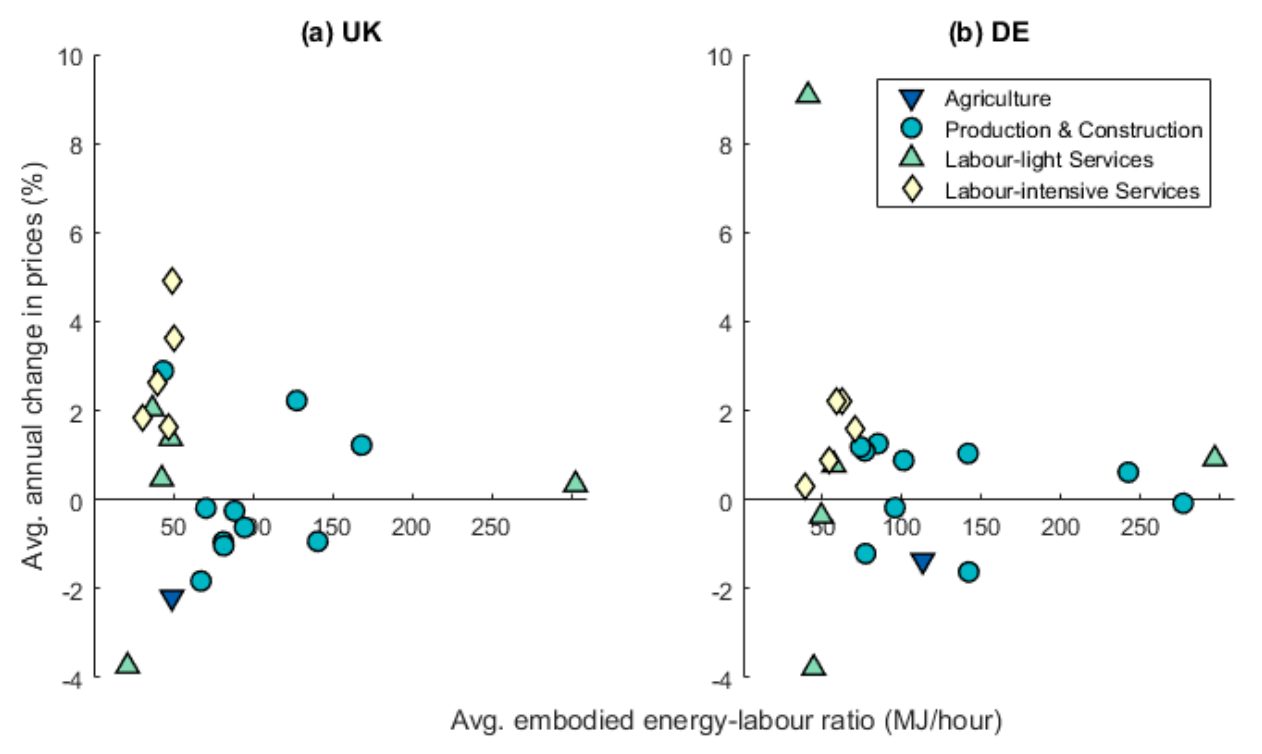

Figure 5. Relationship between change in sector price indices and the average embodied energy-labour ratio in (a) the UK and (b) Germany. Transport sectors are excluded for clarity as they feature average embodied-energy labour ratios above $300 \mathrm{MJ} / \mathrm{h}$.

\section{Discussion}

\subsection{Comparing our Results to the Literature}

To our knowledge, there are no other studies that compare embodied energy intensity to growth rates of embodied labour productivity across sectors. Gazheli, van den Bergh and Antal [18] compare embodied carbon intensity with direct labour productivity growth across sectors in Germany, Spain and Denmark. They do not find evidence for a correlation between embodied carbon intensity and direct labour productivity growth in any of the countries. Our results would suggest that this lack of a correlation could be due to the fact that some of the labour-light services show relatively low levels of embodied energy intensity with relatively high rates of growth in embodied or direct labour productivity. Jackson et al. [19] briefly compare the levels (but not growth rates) of embodied GHG intensities and embodied labour intensity across sectors in the UK or Canada. They highlight that the personal and social services sector provides a very high level of embodied labour intensity with a low level of embodied GHG intensity.

We can also compare our results to the literature on Baumol's cost disease, which includes a discussion on which service sectors can be considered to be part of the 'stagnant' group of sectors with low potential labour productivity growth. Our results are similar to other empirical assessments, even though the other studies use a conventional rather than a supply-chain perspective. Using an analysis of different direct labour productivity measures, Baumol et al. [33] identify the following service sectors in the US to be stagnant according to the majority of measures: finance and insurance; hotels, personal and repair; auto repair and service; movies and amusement; medical, educational and non-profit; government enterprises; government industry. In a more recent study, Maroto and Rubalcaba [62] determine different rates of direct labour productivity growth in different EU service sectors and estimate low or negative rates of direct labour productivity growth $(<1 \%$ per year) in the sectors hotels and restaurants, real estate activities, business services and social \& personal services. They estimate a slightly higher rate of direct labour productivity growth in the public sector $(1.67 \%$ per year), but this is still considerably lower than the direct labour productivity growth they estimate for the manufacturing sectors (5.93\% per year). 
Jackson [10] lists the activities of "nutrition, education, care, maintenance and repair, recreation, craft, creativity, culture" (p. 220) as examples of labour-intensive services desirable for a post-growth economy. The five broad service sectors that we identify as being labour-intensive encompass all of these activities. Our results therefore support the assumptions in the post-growth literature that these activities could potentially be sectors for job creation in a post-growth economy.

The Construction sector presents an interesting case. In both countries it is showing relatively low values of embodied energy intensity. In addition, it is showing negative rates of change in embodied labour productivity, which means that it largely fulfils the two criteria we applied to identify labour-intensive services. However, while our estimated values of embodied energy intensity in the sector are quite low, the construction sector is generally considered to have high environmental intensities with regard to other environmental impacts, especially with regard to overall material use and GHG emissions from cement production [63]. We have therefore not included it in the category of labour-intensive services. Nevertheless, our results highlight that construction activities are labour-intensive and that the sector could therefore provide an important source of jobs in a post-growth economy, as long as it can be made less environmentally intensive, for example in the area of retrofitting houses or in the construction of low-impact housing.

\subsection{Potential Energy Savings from Structural Change}

Our results confirm that most service sectors are less energy intensive than manufacturing and transport sectors, even when calculated using a supply-chain perspective. The picture still holds when the embodied energy-labour ratio is considered, although the distinction is not quite as clear, with some manufacturing sectors showing values similar to service sectors. Overall, a shift in final demand away from sectors with high embodied energy intensity towards labour-intensive services would therefore reduce the energy footprint of final demand in Germany and the UK.

To estimate the potential magnitude of energy footprint reductions we can imagine a radical scenario in which the share in final demand of all sectors with high embodied energy intensity (>3 MJ/EUR) in 2011 is reduced by half, this includes the production sectors as well as the Transport sector and the Agriculture, Forestry Fishing sector. The value of demand reduced in the energy-intensive sectors is redistributed to the five labour-intensive service sectors, according to their shares in demand in 2011, so that overall demand is unchanged. We can then calculate new, hypothetical, energy and labour footprints using the embodied energy and labour intensities for 2011. Such a hypothetical scenario would reduce the total energy footprint of the sectors covered in this study by about $22 \%$ in both Germany and the UK. As our study excludes energy consumption for residential purposes and private transport, the reductions in the total final energy footprint in the UK and Germany would be smaller.

Such reductions in energy footprints would constitute an important step towards reducing environmental impacts. However, they are relatively small, given that the scenario describes structural changes that are very large by historic standards. In addition, the scenario is very simple and might not be achievable in practice as some categories of energy-intensive demand might not be easily reduced because they constitute important human needs, such as food or clothing.

For a post-growth economy, it is not only the overall energy footprint that needs to be reduced by structural change, but also the overall energy-labour ratio. In our scenario the overall embodied energy-labour ratio would be reduced by $8 \%$ and $11 \%$ in Germany and the UK respectively. The potential contribution that structural changes towards labour-intensive services can make to lower the embodied energy-labour ratio is therefore even smaller than the one for the energy footprints. However, a large part of the labour footprint for both countries is employed abroad. The ratio of domestic and foreign labour inputs in the supply chain varies significantly between sectors, with the production sectors and the Agriculture, Forestry, Fishing sector generally being associated with larger proportions of labour employed abroad (Tables A1 and A2, Appendix A). Any shifts towards labour intensive services imagined in the post-growth literature would therefore reduce the energy-labour ratio within the UK 
and Germany and increase employment domestically, even if it does not lead to big changes in the aggregate embodied energy-labour ratio.

The sustainability challenge requires us to find ways to provide for human needs within planetary boundaries. Overall, our results indicate that structural changes towards labour-intensive services can make a contribution to the goals of a post-growth economy and to addressing the sustainability challenge, by reducing energy consumption and creating employment. It is difficult to define how much final energy consumption has to be reduced in developed countries to ensure environmental sustainability. However, we would suggest that the magnitudes of energy savings discussed in this section on their own are unlikely to be sufficient for avoiding environmental crises from climate change and other environmental impacts.

Therefore, it is important to focus on other strategies that can reduce energy use across sectors. One way to achieve this is to increase policy efforts to reduce their energy intensity. This is especially relevant for the service sectors which have generally lagged behind other sectors with regard to energy intensity reductions $[27,64]$. An important question for the post-growth literature is then how such efforts to innovate and reduce energy intensity interact with labour productivity, as there is evidence that increased efforts for environmental innovation increase productivity [65]. Another possibility to reduce energy consumption would be through policies for targeted reductions in unnecessary economic production. This is likely to be most effective in production sectors that have a high energy intensity and already have exhausted many options for easy energy intensity improvements. In those sectors related to land-use change, such as agriculture or forestry, another important objective for the post-growth economy would be to restore the capacity of the land to provide important ecosystem services [66].

Nevertheless, even if the energy savings of high-level shifts towards labour-intensive that we examine here are limited, there might still be other reasons why such shifts towards labour-intensive services have to form an important part of the post-growth transition. Such reasons can include the ability of these sectors to provide meaningful and socially useful work.

\subsection{Baumol's Cost Disease as a Barrier to the Post-Growth Transition}

The theory of Baumol's cost disease rests on a stylised division of the economy in sectors with high labour productivity and sectors with low labour productivity growth. Our results for the UK largely fit with Baumol's theory. There are high rates of growth in embodied labour productivity in production and the labour-light services compared to low rates of growth in the labour-intensive services. We find relative price increase in labour-intensive service sectors relative to high-energy production sectors. In contrast the results for Germany show stagnating value in embodied labour productivity in many of the production and labour-light service sectors that are similar to those in the labour-intensive services.

The diverging results with regard to embodied labour productivity in the production sectors in Germany and the UK highlight that it is important to go beyond the stylised division and take into account local context and complexity. This complexity has also been highlighted in other research on the topic $[35,36]$. The adoption of a supply-chain perspective demonstrates one aspect of this complexity, namely the interconnectedness of the different conventional sectors. Most final products rely on a mix of labour-intensive and non-labour-intensive activities, which shapes the rates of embodied labour productivity improvements. As our results demonstrate, this can lead to considerable differences in the rates of change of labour productivity between direct and embodied measures.

Nevertheless, drawing on our results for the UK and the wider evidence in the literature, we consider that Baumol's cost disease should be taken seriously when developing strategies for a transition to a post-growth economy. At first glance it might appear that Baumol's cost disease already supports a post-growth transition, as it leads to a shift of labour and demand in current prices towards labour-intensive services and might even act to reduce economic growth. However, as a general tendency we would suggest that Baumol's cost disease would act as a barrier to the post-growth transition for two reasons. Firstly, the shift in demand towards labour-intensive services is largely a 
result of price changes and not mirrored in real production. The share of energy-intensive production sectors does not decline strongly in real terms and hence energy demand is not strongly reduced by these changes [28].

Secondly, as Baumol [30] himself argues, some of the fundamental features of the cost disease are working against sustainability concerns. Manufactured goods, which have a high direct energy intensity, are becoming ever cheaper compared to labour intensive services with low direct energy intensity. In addition, the rising relative costs of repair foster a throw-away society. The only reason that Baumol's cost disease produces a shift in labour and output in current prices towards some labour-intensive services is the fact that these services are so important that demand for them is kept up despite increasing relative prices and costs (e.g., health care, education). Other labour-intensive services, which are not essential, such as theatre, become luxury products or are completely priced out of the market [30]. Even those labour-intensive services that are seen as essential and are often publicly provided (e.g., health care) face a continuous uphill battle from rising costs which need to be constantly justified.

Post-growth economics proposes that a sustainable economy will require a much larger share of activities to be concentrated in labour-intensive services. Baumol's cost disease suggests that a shift of economic activity towards such sectors would provide considerable challenges as these sectors will constantly struggle with rising relative costs and prices. An important question for the post-growth economics literature is therefore how to change the economic system to reduce the disadvantage that labour-intensive services face from Baumol's cost disease. This presents a difficult challenge as Baumol's cost disease relates to some fundamental features of our market economy, such as competition and the important role of labour costs. Our analysis shows that many of the sectors showing low or negative price inflation also have a higher energy-labour ratio. A reform of the tax system that moves taxes away from labour and onto energy use or GHG emissions could therefore make a start in addressing the disadvantage faced by labour-intensive services. Such tax reforms are a common suggestion in the post-growth literature [67]. Other policies could be targeted at specific labour-intensive services, for example obligations for companies to offer repair services together with their products. Another possible way to increase labour-intensive services would be to increase the non-market provision of such services through communities or the state, especially where such services are already provided in a non-market environment.

\subsection{Structural Change and Economic Growth are Intertwined}

Our results for Germany and the UK do not only show differences with regard to rates of change and embodied labour productivity in production sectors, but also the economy as a whole. The embodied labour productivity of all demand sectors covered in this study is essentially stagnant in Germany, while it shows a positive rate of growth in the UK. Similarly, the overall rate of price inflation is well below $1 \%$ in Germany but considerably higher in the UK.

The diverging results between the two countries therefore highlight another key feature of the wider literature on structural change. This is the fact that structural change is closely linked to the process of economic growth, as stressed by Kuznets [68]. Two of the main causes of structural change that have been identified in the literature are differential rates of labour productivity growth in different sectors [31] and changes in demand composition associated with rising incomes [24]. Both of these mechanisms can be expected to operate only weakly in an economy that is not showing growth in aggregate labour productivity, income and demand. Without high productivity growth in at least some sectors, we also would not expect the manifestation of Baumol's cost disease.

This raises important questions for post-growth economists as they generally envision structural change towards labour-intensive services in a non-growing economy or even as a strategy to lower economic growth. However, the literature on structural change so far has very little insights to offer on how structural changes can be achieved in a non-growing economy. 


\section{Conclusions}

Our current economic system is not sustainable as it is increasingly destroying the ecological life support systems of our planet. To address the sustainability challenge, we need to find ways to rapidly reverse environmental destruction while simultaneously meeting human needs and improving living conditions. Post-growth economists propose that structural changes in our economy away from material production and towards labour-intensive services, such as health care, education, arts and crafts or repair services, can make an important contribution to addressing the sustainability challenge by reducing the environmental impact of the economy and provide meaningful jobs.

Our study produces some empirical evidence regarding the realisation of this proposal by investigating the relationship between embodied energy intensity and embodied labour productivity of final demand sectors in the UK and Germany between 1995 and 2011. Specifically, we investigate three questions, namely whether service sectors feature lower levels of embodied energy intensity than other sectors, which service sectors can be considered labour-intensive and whether these labour-intensive service sectors might be affected by Baumol's cost disease. Our results confirm some of the assumptions in the post-growth economics literature but also raise some important challenges.

Firstly, we confirm that service sectors show lower values of embodied final energy intensity than other sectors and we identify five sectors as labour-intensive, combing low levels of embodied energy intensity with low rates of growth in embodied labour productivity. These include Hotels and Restaurants, Public Administration, Education, Health Care and Other Services. Given the lower embodied energy intensity of these sectors, structural changes towards these labour-intensive service sectors would likely reduce the energy footprint of the German and UK economies.

Secondly, however, our results also suggest that the magnitude of reductions in energy footprints that can be achieved from structural changes towards labour-intensive services are relatively small and, on their own, are unlikely to be sufficient for reducing the environmental impacts of the respective economies to sustainable levels. This is the case because large fractions of demand as well as the labour footprint are already concentrated in sectors with low embodied energy intensity. While labour-intensive service sectors provide very important services for human flourishing, increasing their share in the economy is no panacea for reducing environmental impact. To achieve rapid reductions in energy footprints it is therefore important to achieve improvements in energy intensity within sectors as well as reductions in overall economic demand and production.

Lastly, our results highlight some potential challenges to achieving such structural changes towards labour-intensive services for a post-growth transition. For the UK we find some support for the theory of Baumol's cost disease with rates of price inflation in labour-intensive services being higher than in other sectors, especially compared to production sectors with high embodied energy-labour ratio. Baumol's cost disease suggests that the tendency of our economic system to chase labour productivity improvements poses a considerable challenge to labour-intensive sectors. As it is undesirable and/or difficult to improve labour productivity in these sectors, they face continuously rising costs and prices relative to other sectors that are able to improve labour productivity. Such rising costs threaten their existence in the market place or their political justification, if they are provided publicly, and therefore provide a potential barrier to the expansion of labour-intensive services envisioned in the post-growth literature.

For Germany we do not find evidence supporting Baumol's cost disease as rates of growth in embodied labour productivity and price inflation are low across the whole economy, including the manufacturing sectors. These results highlight another challenge to the post-growth proposals, namely the fact that structural changes are closely intertwined with the process of economic growth. There are currently no theories to explain how structural changes might happen in an economy that is not growing. 
Our research improves our understanding of the implications and challenges of structural changes towards labour-intensive services. However, it also highlights some important unanswered questions for the post-growth transition: How can we reduce the environmental impacts of labour-intensive services even further? How can structural changes towards labour-intensive services be achieved without further economic growth? How can we create an economic environment that allows such labour-intensive services to flourish in the face of increasing labour productivity in other sectors? If we are serious about fostering labour-intensive, community-based services as part of a post-growth transition we need further research to answer these questions.

Supplementary Materials: Supplementary information on the construction of the energy extension vector are available online at http://www.mdpi.com/2071-1050/12/3/962/s1.

Author Contributions: Conceptualization; L.H., J.B., P.G.T. and T.J.F.; Methodology: L.H., J.B., P.G.T. and T.J.F.; Formal Analysis: L.H.; Data Curation: L.H.; Writing—Original Draft Preparation: L.H.; Writing-Review \& Editing: L.H., J.B., P.G.T. and T.J.F.; Visualization: L.H.; Supervision: J.B., P.G.T. and T.J.F.; Funding Acquisition: J.B. and P.G.T. All authors have read and agreed to the published version of the manuscript.

Funding: This research was primarily funded by the UK Energy Research Centre, supported by the UK Research Councils under EPSRC award EP/L024756/1. J.B.'s, P.G.T.'s and T.J.F.'s research is also supported by the Centre for Research on Energy Demand Solutions (CREDS) [EPSRC award EP/R035288/1].

Conflicts of Interest: The authors declare no conflict of interest.

Appendix A. Regional Distribution of Labour Footprints

Table A1. Distribution of UK sectoral labour footprints by source region (\%).

\begin{tabular}{|c|c|c|c|c|c|c|c|}
\hline Demand Sector & UK & $\begin{array}{l}\text { Rest of } \\
\text { Europe }\end{array}$ & $\begin{array}{l}\text { North } \\
\text { America }\end{array}$ & $\begin{array}{c}\text { South \& Central } \\
\text { America }\end{array}$ & China & $\begin{array}{c}\text { Asia and } \\
\text { Oceania }\end{array}$ & Africa \\
\hline \multicolumn{8}{|l|}{ Agriculture } \\
\hline Agriculture, Forestry, Fishing & 4.8 & 4.9 & 0.4 & 6.6 & 2.4 & 30.2 & 50.7 \\
\hline \multicolumn{8}{|l|}{ Production \& Construction } \\
\hline Mineral Products & 19.1 & 6.4 & 1.3 & 2.2 & 4.5 & 53.5 & 13.0 \\
\hline Food, Beverages and Tobacco & 14.2 & 12.8 & 1.1 & 4.1 & 6.7 & 46.1 & 15.0 \\
\hline Textiles, Clothes, Leather & 3.7 & 6.2 & 0.6 & 1.5 & 36.9 & 45.4 & 5.6 \\
\hline Metals and Fabricated Metal Products & 21.2 & 13.2 & 3.0 & 2.3 & 8.8 & 45.1 & 6.4 \\
\hline Machinery, Electrical, Equipment, Computers & 8.5 & 14.1 & 3.5 & 1.8 & 27.5 & 39.2 & 5.4 \\
\hline Transport Equipment & 11.4 & 22.1 & 3.1 & 2.3 & 8.3 & 45.8 & 7.0 \\
\hline Other Manufacturing & 9.4 & 12.8 & 4.5 & 2.2 & 21.4 & 43.4 & 6.3 \\
\hline Construction & 73.0 & 4.1 & 0.8 & 0.8 & 3.3 & 14.5 & 3.5 \\
\hline \multicolumn{8}{|l|}{ Labour-light Services } \\
\hline IT and Communication & 76.9 & 4.3 & 1.0 & 0.5 & 1.7 & 11.7 & 3.8 \\
\hline Business Services & 61.9 & 6.1 & 3.1 & 1.0 & 2.9 & 20.8 & 4.3 \\
\hline \multicolumn{8}{|l|}{ Labour-intensive Services } \\
\hline Hotels and Restaurants & 28.6 & 7.8 & 3.2 & 1.3 & 14.3 & 22.6 & 22.3 \\
\hline Public Administration & 70.0 & 4.0 & 1.4 & 0.8 & 3.0 & 17.0 & 3.7 \\
\hline Health & 72.7 & 2.2 & 0.6 & 0.5 & 1.7 & 20.0 & 2.3 \\
\hline Education & 62.7 & 3.2 & 1.1 & 0.9 & 3.4 & 25.0 & 3.6 \\
\hline Other Services & 71.2 & 4.0 & 1.3 & 0.8 & 2.4 & 16.5 & 4.0 \\
\hline
\end{tabular}


Table A2. Distribution of German sectoral labour footprints by source region.

\begin{tabular}{|c|c|c|c|c|c|c|c|}
\hline Demand & Germany & $\begin{array}{l}\text { Rest of } \\
\text { Europe }\end{array}$ & $\begin{array}{l}\text { North } \\
\text { America }\end{array}$ & $\begin{array}{c}\text { South \& Central } \\
\text { America }\end{array}$ & China & $\begin{array}{l}\text { Asia and } \\
\text { Oceania }\end{array}$ & Africa \\
\hline Agriculture, Forestry, Fishing & 4.5 & 7.5 & 0.4 & 7.8 & 2.9 & 38.4 & 38.6 \\
\hline Mineral Products & 12.6 & 10.5 & 1.6 & 3.3 & 5.8 & 53.3 & 13.0 \\
\hline Food, Beverages and Tobacco & 19.8 & 14.1 & 0.8 & 5.8 & 8.1 & 32.4 & 19.0 \\
\hline Textiles, Clothes, Leather & 2.8 & 11.9 & 0.7 & 2.0 & 34.0 & 41.8 & 6.8 \\
\hline Metals and Fabricated Metal Products & 20.9 & 24.1 & 1.6 & 2.3 & 7.0 & 37.2 & 6.9 \\
\hline Machinery, Electrical, Equipment, Computers & 12.7 & 17.0 & 2.6 & 1.9 & 23.9 & 36.4 & 5.6 \\
\hline Transport Equipment & 14.8 & 24.8 & 4.2 & 4.0 & 10.2 & 33.7 & 8.2 \\
\hline Other Manufacturing & 22.0 & 23.5 & 1.6 & 2.0 & 13.5 & 30.9 & 6.5 \\
\hline Construction & 53.2 & 10.5 & 1.2 & 1.0 & 6.3 & 22.6 & 5.2 \\
\hline \multicolumn{8}{|l|}{ Labour-light Services } \\
\hline IT and Communication & 58.8 & 7.7 & 2.1 & 0.6 & 2.9 & 19.9 & 8.0 \\
\hline Business Services & 72.8 & 4.5 & 4.3 & 0.7 & 2.2 & 12.8 & 2.8 \\
\hline \multicolumn{8}{|l|}{ Labour-intensive Services } \\
\hline Hotels and Restaurants & 40.6 & 7.0 & 4.9 & 1.8 & 11.7 & 17.2 & 16.8 \\
\hline Public Administration & 67.2 & 5.4 & 2.9 & 1.1 & 3.4 & 14.6 & 5.3 \\
\hline Health & 80.9 & 3.3 & 1.5 & 0.5 & 1.8 & 9.1 & 2.8 \\
\hline Education & 66.1 & 5.8 & 1.4 & 1.7 & 4.3 & 15.3 & 5.4 \\
\hline Other Services & 65.9 & 5.1 & 1.6 & 0.8 & 4.2 & 17.2 & 5.2 \\
\hline
\end{tabular}

\section{Appendix B. Results Excluding the Financial Crisis}

Table A3. Rates of change in embodied energy intensity and embodied labour productivity as well as in the embodied energy-labour ratio for domestic demand sectors between 1995 and 2006. Intensities represent embodied energy and labour inputs per unit real demand (const. 2010 EUR).

\begin{tabular}{|c|c|c|c|c|c|c|}
\hline \multirow[b]{3}{*}{ Sector } & \multicolumn{6}{|c|}{ Cumulative Annual Growth Rate between 1995 and 2006 (\%) } \\
\hline & \multicolumn{3}{|c|}{ UK } & \multicolumn{3}{|c|}{ DE } \\
\hline & $\begin{array}{c}\text { Energy } \\
\text { Intensity }\end{array}$ & $\begin{array}{l}\text { Labour } \\
\text { Prod. }\end{array}$ & Price Index & $\begin{array}{c}\text { Energy } \\
\text { Intensity }\end{array}$ & $\begin{array}{l}\text { Labour } \\
\text { Prod. }\end{array}$ & Price Index \\
\hline \multicolumn{7}{|l|}{ Agriculture } \\
\hline Agriculture, Forestry, Fishing & -6.1 & 4.7 & -2.2 & -2.8 & 3.1 & -1.1 \\
\hline \multicolumn{7}{|l|}{ Production \& Construction } \\
\hline Mineral Products & 3.7 & -2.6 & 3.1 & 0.5 & -0.5 & -0.5 \\
\hline Food, Beverages and Tobacco & 0.0 & -1.0 & 2.7 & -0.3 & -1.0 & 0.9 \\
\hline Textiles, Clothes, Leather & 1.1 & 3.4 & 0.3 & -2.0 & -0.5 & -0.2 \\
\hline Paper, printing, Publishing & 1.5 & 0.5 & 3.3 & 0.5 & 1.3 & -0.8 \\
\hline Chemicals & -4.1 & 3.3 & -0.8 & -1.6 & 0.8 & -0.8 \\
\hline Metals and Fabricated Metal Products & -4.8 & 3.0 & 0.1 & -2.7 & 0.7 & 0.5 \\
\hline Machinery, Electrical, Equipment, Computers & -4.0 & 3.2 & -0.5 & -1.7 & 0.3 & -1.6 \\
\hline Transport Equipment & -3.4 & 2.3 & 0.9 & -0.5 & -2.0 & 1.3 \\
\hline Other Manufacturing & 1.0 & -0.3 & 3.5 & 0.3 & -0.1 & 0.8 \\
\hline Construction & -0.4 & -0.8 & 6.2 & 0.0 & -0.2 & -0.2 \\
\hline \multicolumn{7}{|l|}{ Labour-light Services } \\
\hline Wholesale and Retail Trade & -2.6 & 3.3 & 3.6 & -1.0 & 1.8 & -0.6 \\
\hline Transport & -2.0 & 1.3 & 1.9 & 0.5 & -0.1 & 0.9 \\
\hline Finance and Insurance & -5.9 & 5.1 & 2.1 & 8.9 & -6.5 & 12.0 \\
\hline Real Estate Activities & -2.9 & 1.2 & 1.9 & -0.9 & 1.3 & -0.6 \\
\hline IT and Communication & -7.7 & 8.4 & -3.0 & -0.7 & 3.1 & -3.3 \\
\hline Business Services & -3.6 & 2.4 & 3.2 & 2.1 & -1.4 & 0.6 \\
\hline \multicolumn{7}{|l|}{ Labour-intensive Services } \\
\hline Hotels and Restaurants & -1.0 & 0.0 & 5.1 & 1.0 & 0.3 & 2.4 \\
\hline Public Administration & -1.4 & -0.9 & 4.8 & -1.5 & 0.2 & 0.7 \\
\hline Health & -0.9 & -2.5 & 7.3 & -1.5 & -0.8 & 1.9 \\
\hline Education & 0.7 & -0.3 & 4.6 & -1.2 & 0.1 & 0.2 \\
\hline Other Services & 0.0 & -0.6 & 6.3 & 0.3 & -0.8 & 1.6 \\
\hline Total domestic demand & -1.6 & 0.6 & 3.7 & -0.9 & 0.1 & 0.5 \\
\hline
\end{tabular}



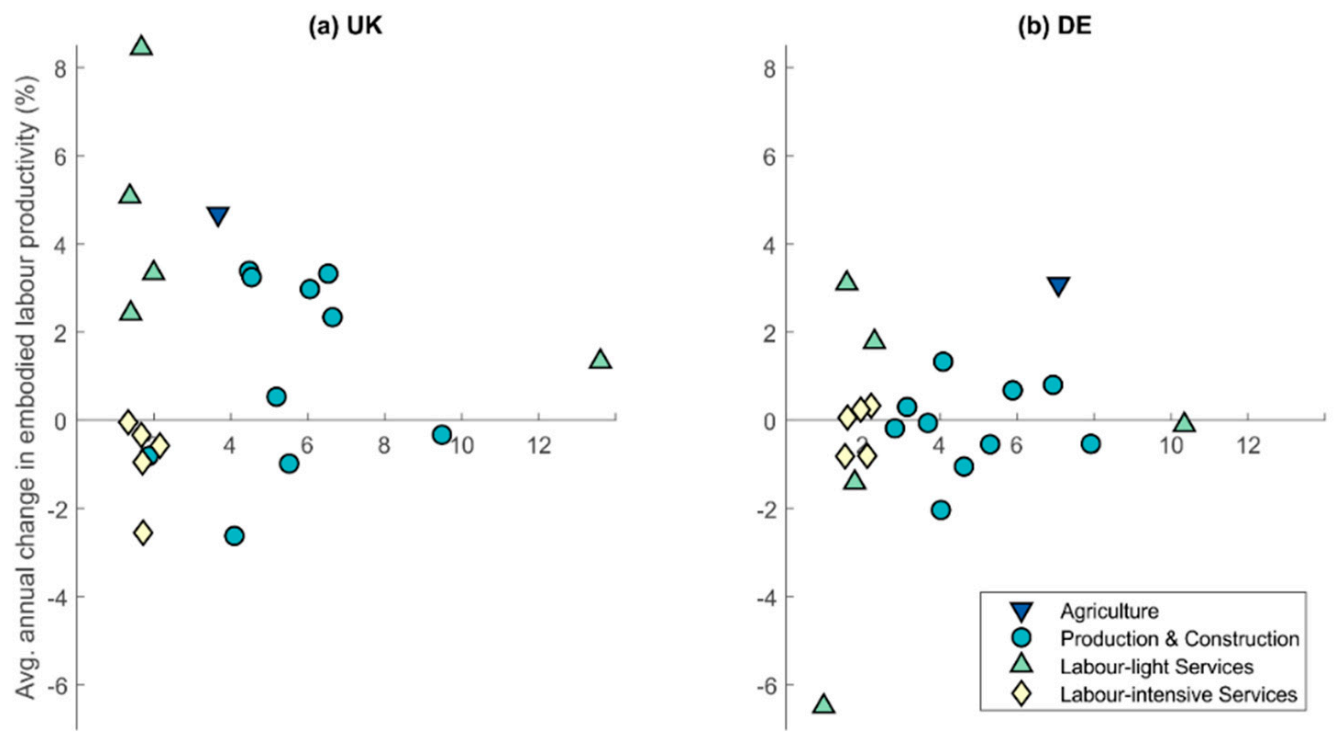

Avg. embodied energy intensity (MJ/const. 2010 EUR)

Figure A1. Relationship between change in embodied labour productivity and the average embodied energy intensity for domestic demand sectors between 1995 and 206 in (a) the UK and (b) Germany.
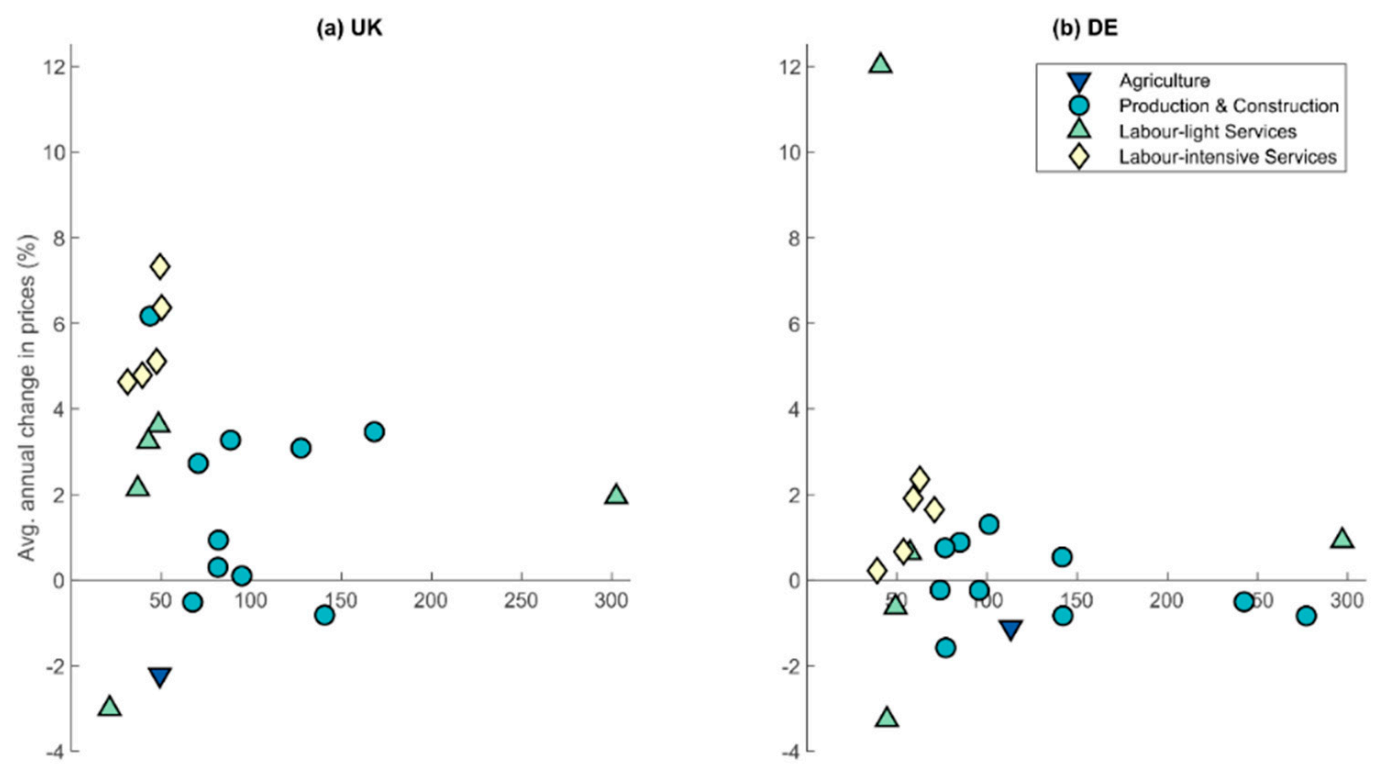

Avg. embodied energy-labour ratio (MJ/hour)

Figure A2. Relationship between change in sector price indices and the average embodied energy-labour ratio between 1995 and 2006 in (a) the UK and (b) Germany. 


\section{Appendix C. Direct Labour Productivity Growth}

Table A4. Sectoral rates of change in direct labour productivity in the UK and Germany between 1995 and 2011.

\begin{tabular}{|c|c|c|}
\hline \multirow[t]{2}{*}{ Sectors } & \multicolumn{2}{|c|}{ Cumulative Rate of Change in Direct Labour Productivity * $(\%)$} \\
\hline & UK & DE \\
\hline \multicolumn{3}{|l|}{ Agriculture } \\
\hline Agriculture, Forestry, Fishing & 4.1 & 4.3 \\
\hline \multicolumn{3}{|l|}{ Production \& Construction } \\
\hline Mineral Products & -1.2 & 3.3 \\
\hline Food, Beverages and Tobacco & 3.7 & -1.3 \\
\hline Textiles, Clothes, Leather & 4.8 & 3.7 \\
\hline Paper, printing, Publishing & 3.0 & 6.4 \\
\hline Chemicals & 6.4 & 2.1 \\
\hline Metals and Fabricated Metal Products & 3.1 & 2.0 \\
\hline Machinery, Electrical, Equipment, Computers & 5.6 & 4.2 \\
\hline Transport Equipment & 5.4 & 3.3 \\
\hline Other Manufacturing & 3.2 & 2.5 \\
\hline Construction & -0.2 & 0.1 \\
\hline \multicolumn{3}{|l|}{ Labour-light Services } \\
\hline Wholesale and Retail Trade & 2.6 & 2.0 \\
\hline Transport & 3.0 & 4.6 \\
\hline Finance and Insurance & 6.6 & -0.6 \\
\hline Real Estate Activities & - & - \\
\hline IT and Communication & 7.9 & 4.2 \\
\hline Business Services & 3.8 & -2.2 \\
\hline \multicolumn{3}{|l|}{ Labour-intensive Services } \\
\hline Hotels and Restaurants & 1.0 & 1.9 \\
\hline Public Administration & -0.6 & 1.7 \\
\hline Health & -2.8 & -1.7 \\
\hline Education & 1.1 & 1.0 \\
\hline Other Services & 0.8 & 0.2 \\
\hline Total & 2.4 & 1.7 \\
\hline
\end{tabular}

*: Direct labour productivity is calculated as sectoral GVA (in constant 2010 prices) per hour of work in the sector, using data from EXIOBASE V3.4 and GVA deflators from Eurostat.

\section{References}

1. Report of the World Commission on Environment and Development: Our Common Future. Available online: https://sustainabledevelopment.un.org/content/documents/5987our-common-future.pdf (accessed on 10 January 2020).

2. United Nations. Transforming our world: The 2030 Agenda for Sustainable Development. Available online: https://sustainabledevelopment.un.org/content/documents/21252030\%20Agenda\%20for\% 20Sustainable\%20Development\%20web.pdf (accessed on 10 January 2020).

3. Rockström, J.; Steffen, W.; Noone, K. A safe operating space for humanity. Nature 2009, 461, 472. [CrossRef] [PubMed]

4. Steffen, W.; Richardson, K.; Rockström, J.; Cornell, S.; Fetzer, I.; Bennett, E.; Biggs, R.; Carpenter, S. Planetary boundaries: Guiding human development on a changing planet. Science 2015, 347, 1259855. [CrossRef]

5. Hickel, J.; Kallis, G. Is Green Growth Possible? New Polit. Econ. 2019. [CrossRef]

6. Opršal, Z.; Harmáček, J.; Pavlík, P.; Machar, I. What factors can influence the expansion of protected areas around the world in the context of international environmental and development goals? Probl. Ekorozw. 2018, 13, 145-157.

7. O'Neill, D.W.; Fanning, A.L.; Lamb, W.F.; Steinberger, J.K. A good life for all within planetary boundaries. Nat. Sustain. 2018, 1, 88. [CrossRef]

8. Raupach, M.R.; Marland, G.; Ciais, P.; Le Quéré, C.; Canadell, J.G.; Klepper, G.; Field, C.B. Global and regional drivers of accelerating $\mathrm{CO}_{2}$ emissions. Proc. Natl. Acad. Sci. USA 2007, 104, 10288-10293. [CrossRef]

9. Peters, G.P.; Andrew, R.M.; Canadell, J.G.; Fuss, S.; Jackson, R.B.; Korsbakken, J.I.; Le Quéré, C.; Nakicenovic, N.; Marshall, D.P.; Ambaum, M.H.P.; et al. Key indicators to track current progress and future ambition of the Paris Agreement. Nat. Clim. Chang. 2017, 7, 79-81. [CrossRef]

10. Jackson, T. Prosperity without Growth, 2nd ed.; Routledge: Oxon, UK, 2017. 
11. D'Alisa, G.; Demaria, F.; Kallis, G. Degrowth: A Vocabulary for a New Era; Routledge: London, UK, 2015.

12. Kallis, G. In defence of degrowth. Ecol. Econ. 2011, 70, 873-880. [CrossRef]

13. Daly, H.E. Sustainable Development: From Concept and Theory to Operational Principles. Popul. Dev. Rev. 1990, 16, 25-43. [CrossRef]

14. O'Neill, D.W. What Should Be Held Steady in a Steady-State Economy? Interpreting Daly's Definition at the National Level. J. Ind. Ecol. 2015, 19, 552-563. [CrossRef]

15. Jackson, T. New economy. In Degrowth: A Vocabulary for a New Era; D'Alisa, G., Demaria, F., Kallis, G., Eds.; Routledge: London, UK, 2015.

16. Kallis, G.; Kerschner, C.; Martinez-Alier, J. The economics of degrowth. Ecol. Econ. 2012, 84, 172-180. [CrossRef]

17. Sakai, M.; Owen, A.; Barrett, J. The UK's emissions and employment footprints: Exploring the trade-offs. Sustainability 2017, 9, 1242. [CrossRef]

18. Gazheli, A.; Van Den Bergh, J.; Antal, M. How realistic is green growth? Sectoral-level carbon intensity versus productivity. J. Clean. Prod. 2016, 129, 449-467. [CrossRef]

19. Jackson, T.; Drake, B.; Victor, P.A.; Kratena, K.; Sommer, M. Foundations for an Ecological Macroeconomics: Literature review and model development. Available online: https:/www.wifo.ac.at/jart/prj3/wifo/ main.jart?rel=en\&content-id=1436057251192\&publikation_id=47497\&detail-view=yes\&sid=2 (accessed on 10 January 2020).

20. Wiedmann, T.; Minx, J.; Barrett, J.; Wackernagel, M. Allocating ecological footprints to final consumption categories with input-output analysis. Ecol. Econ. 2006, 56, 28-48. [CrossRef]

21. Barrett, J.; Peters, G.; Wiedmann, T.; Scott, K.; Lenzen, M.; Roelich, K.; Le Quéré, C. Consumption-based GHG emission accounting: A UK case study. Clim. Policy 2013, 13, 451-470. [CrossRef]

22. Wiedmann, T.O.; Schandl, H.; Lenzen, M.; Moran, D.; Suh, S.; West, J.; Kanemoto, K. The material footprint of nations. Proc. Natl. Acad. Sci. USA 2015, 112, 6271-6276. [CrossRef]

23. Lan, J.; Malik, A.; Lenzen, M.; McBain, D.; Kanemoto, K. A structural decomposition analysis of global energy footprints. Appl. Energy 2016, 163, 436-451. [CrossRef]

24. Pasinetti, L.L. Structural Economic Dynamics: A Theory of the Economic Consequences of Human Learning; Cambridge University Press: Cambridge, UK, 1993.

25. Pasinetti, L.L. Structural Change and Economic Growth: A Theoretical Essay on the Dynamics of the Wealth of Nations; Cambridge University Press: Cambridge, UK, 1981.

26. Mulder, P.; de Groot, H.L.F. International Comparisons of Sectoral Energy-and Labour-Productivity Performance; Tinbergen Institute Discussion Paper No 2004-007/3; Tinbergen Institute: Amsterdam, The Netherlands, 2004.

27. Mulder, P.; de Groot, H.L.F.; Pfeiffer, B. Dynamics and determinants of energy intensity in the service sector: A cross-country analysis, 1980-2005. Ecol. Econ. 2014, 100, 1-15. [CrossRef]

28. Henriques, S.T.; Kander, A. The modest environmental relief resulting from the transition to a service economy. Ecol. Econ. 2010, 70, 271-282. [CrossRef]

29. Druckman, A.; Mair, S. Wellbeing, Care and Robots: Prospects for Good Work in the Health and Social Care Sector; CUSP Working Paper No 21; Centre for Understanding Sustainable Prosperity: Surrey, UK, 2019.

30. Baumol, W.J. The Cost Disease: Why Computers Get Cheaper and Health Care Doesn't; Yale University Press: New Haven, CT, USA, 2012.

31. Baumol, W.J. Macroeconomics of Unbalanced Growth: The Anatomy of Urban Crisis. Am. Econ. Rev. 1967, 57, 415-426.

32. Baumol, W.J.; Bowen, W. On the Performing Arts: The Anatomy of Their Economic Problems. Am. Econ. Rev. 1965, 55, 495-502.

33. Baumol, W.J.; Batey Blackman, S.A.; Wolff, E.N. Unbalanced Growth Revisited: Asymptotic Stagnancy and New Evidence. Am. Econ. Rev. 1985, 75, 806-817.

34. Nordhaus, W.D. Baumol's diseases: A macroeconomic perspective. BE J. Macroecon. 2006, 8, 1-39.

35. Fernandez, R.; Palazuelos, E. European Union Economies Facing "Baumol's Disease" within the Service Sector. J. Common Mark. Stud. 2012, 50, 231-249. [CrossRef]

36. Hartwig, J. Testing the Baumol-Nordhaus model with EU KLEMS data. Rev. Income Wealth 2011, 57, 471-489. [CrossRef]

37. Oh, W.; Kim, K. The baumol diseases and the Korean economy. Emerg. Mark. Financ. Trade 2015, 51, S214-S223. [CrossRef] 
38. Hartwig, J. Structural change, aggregate demand and employment dynamics in the OECD, 1970-2010. Struct. Chang. Econ. Dyn. 2015, 34,36-45. [CrossRef]

39. Hartwig, J. Testing the growth effects of structural change. Struct. Chang. Econ. Dyn. 2012, 23, 11-24. [CrossRef]

40. Miller, R.E.; Blair, P.D. Input-Output Analysis: Foundations and Extensions; Cambridge University Press: Cambridge, UK, 2009.

41. Owen, A.; Brockway, P.; Brand-Correa, L.; Bunse, L.; Sakai, M.; Barrett, J. Energy consumption-based accounts: A comparison of results using different energy extension vectors. Appl. Energy 2017, 190, 464-473. [CrossRef]

42. Stadler, K.; Wood, R.; Bulavskaya, T.; Södersten, C.J.; Simas, M.; Schmidt, S.; Usubiaga, A.; Acosta-Fernández, J.; Kuenen, J.; Bruckner, M.; et al. EXIOBASE 3: Developing a Time Series of Detailed Environmentally Extended Multi-Regional Input-Output Tables. J. Ind. Ecol. 2018, 22, 502-515. [CrossRef]

43. Brockway, P.E.; Owen, A.; Brand-Correa, L.I.; Hardt, L. Estimation of global final stage energy-return-on-investment for fossil fuels with comparison to renewable energy sources. Nat. Energy 2019, 4, 612-621. [CrossRef]

44. Gujarati, D. Basic Econometrics, 3rd ed.; McGraw-Hill: New York, NY, USA, 1995.

45. Peck, J.; Theodore, N. Variegated capitalism. Prog. Hum. Geogr. 2007, 31, 731-772. [CrossRef]

46. Eurostat. Eurostat Database 2018; Eurostat: Luxembourg, 2018.

47. Lequiller, F.; Blades, D. Distinguishing between volume and price increases. In Understanding the National Accounts; OECD Publishing: Paris, France, 2014; pp. 47-77.

48. IEA. IEA World Energy Statistics 2018 Edition: Database Documentation; IEA: Paris, France, 2018.

49. Department for Business Energy \& Industrial Strategy. Energy Consumption in the UK; Department for Business Energy \& Industrial Strategy: London, UK, 2016.

50. AG Energiebilanzen Bilanzen 1990-2017. Available online: https://ag-energiebilanzen.de/7-0-Bilanzen-1990-2017.html (accessed on 7 February 2019).

51. Schlomann, B.; Steinbach, J.; Kleeberger, H.; Geiger, B.; Pich, A.; Gruber, E.; Mai, M.; Gerspacher, A.; Schiller, W. Energieverbrauch des Sektors Gewerbe, Handel, Dienstleistungen (GHD) in Deutschland für die Jahre 2007 bis 2010; Bundesministerium für Wirtschaft und Technology (BMWi): Berlin, Germany, 2013.

52. Schlomann, B.; Gruber, E.; Geiger, B.; Kleeberger, H.; Wehmhörner, U.; Herzog, T.; Konopka, D.-M. Energieverbrauch des Sektors Gewerbe, Handel, Dienstleistungen (GHD) für die Jahre 2004 bis 2006; Bundesministerium für Wirtschaft und Technologie (BMWi): Berlin, Germany, 2009.

53. Schlomann, B.; Gruber, E.; Eichhammer, W.; Kling, N.; Diekmann, J.; Ziesing, H.-J.; Rieke, H.; Wittke, F.; Herzog, T.; Barbosa, M.; et al. Energieverbrauch der privaten Haushalte und des Sektors Gewerbe, Handel, Dienstleistungen (GHD); Bundesministerium für Wirtschaft und Arbeit: Berlin, Germany, 2004.

54. Geiger, B.; Gruber, E.; Megele, W. Energieverbrauch und Einsparung in Gewerbe, Handel und Dienstleistung; Springer Verlag: Berlin/Heidelberg, Germany, 1999.

55. Adler, W. Berichtsmodul Verkehr und Umwelt: Band 14 der Schriftenreihe Beiträge zu den Umweltökonomischen Gesamtrechnungen; Statistisches Bundesamt: Wiesbaden, Germany, 2005.

56. Statistisches Bundesamt. (Destatis) Umweltökonomische Gesamtrechnungen: Transportleistungen und Energieverbrauch im Straßenverkehr 2005-2016; Statistisches Bundesamt: Wiesbaden, Germany, 2018.

57. Owen, A.; Steen-Olsen, K.; Barrett, J.; Wiedmann, T.; Lenzen, M. A structural decomposition approach to comparing MRIO databases. Econ. Syst. Res. 2014, 26, 262-283. [CrossRef]

58. Peters, G.P.; Davis, S.J.; Andrew, R. A synthesis of carbon in international trade. Biogeosciences 2012, 9, 3247-3276. [CrossRef]

59. Lenzen, M.; Wood, R.; Wiedmann, T. Uncertainty Analysis for Multi-Region Input-Output Models-A Case Study of the UK's Carbon Footprint. Econ. Syst. Res. 2010, 22, 43-63. [CrossRef]

60. Inklaar, R.; Timmer, M.P.; van Ark, B. Market services productivity across Europe and the US. Econ. Policy 2008, 23, 140-194.

61. Christophers, B. Making finance productive. Econ. Soc. 2011, 40, 112-140. [CrossRef]

62. Maroto, A.; Rubalcaba, L. Services productivity revisited. Serv. Ind. J. 2008, 28, 337-353. [CrossRef]

63. Giesekam, J.; Barrett, J.; Taylor, P.; Owen, A. The greenhouse gas emissions and mitigation options for materials used in UK construction. Energy Build. 2014, 78, 202-214. [CrossRef] 
64. Hardt, L.; Owen, A.; Brockway, P.; Heun, M.K.; Barrett, J.; Taylor, P.G.; Foxon, T.J. Untangling the drivers of energy reduction in the UK productive sectors: Efficiency or offshoring? Appl. Energy 2018, 223, 124-133. [CrossRef]

65. Aldieri, L.; Kotsemir, M.; Paolo Vinci, C. Environmental innovations and productivity: Empirical evidence from Russian regions. Resour. Policy 2019, 101444. [CrossRef]

66. Pechanec, V.; Kilianová, H.; Tangwa, E.; Vondráková, A.; Machar, I. What is the development capacity for provision of ecosystem services in the Czech Republic? Sustainability 2019, 11, 4273. [CrossRef]

67. Cosme, I.; Santos, R.; O'Neill, D.W. Assessing the degrowth discourse: A review and analysis of academic degrowth policy proposals. J. Clean. Prod. 2017, 149, 321-334. [CrossRef]

68. Kuznets, S. Modern Economic Growth: Findings and reflections. Am. Econ. Rev. 1973, 63, 247-258.

(C) 2020 by the authors. Licensee MDPI, Basel, Switzerland. This article is an open access article distributed under the terms and conditions of the Creative Commons Attribution (CC BY) license (http://creativecommons.org/licenses/by/4.0/). 